\author{
UNIVERSITY OF MINNESOTA \\ ST. ANTHONY FALLS LABORATORY \\ Engineering, Environmental and Geophysical Fluid Dynamics
}

Project Report No. 453

\title{
Phosphorus Dynamics in Jessie Lake: Mass Flux across the Sediment-Water Interface
}

\author{
by \\ Hong Wang, Miki Hondzo \\ and \\ Brenda Stauffer
}



Prepared for

ITASCA COUNTY SOIL AND WATER CONSERVATION DISTRICT

Grand Rapids, Minnesota

March 2002

Minneapolis, Minnesota 


\title{
UNIVERSITY OF MINNESOTA \\ ST. ANTHONY FALLS LABORATORY \\ Engineering, Environmental and Geophysical Fluid Dynamics
}

Project Report No. 453

\section{Phosphorus Dynamics in Jessie Lake: Mass Flux across the Sediment-Water Interface}

\author{
by \\ Hong Wang, Miki Hondzo \\ and \\ Brenda Stauffer \\ Prepared for \\ ITASCA COUNTY SOIL AND WATER CONSERVATION DISTRICT \\ Grand Rapids, Minnesota
}

March 2002

Minneapolis, Minnesota 
The University of Minnesota is committed to the policy that all persons shall have equal access to its programs, facilities, and employment without regard to race, religion, color, sex, national origin, handicap, age or veteran status.

Prepared for: Itasca county Soil \& Water Conservation District Last Revised: 3/29/2002

Disk Locators: PR453cov-JessieLake.doc; Jessie Lake.doc;

(Zip Disk \#40\MH Jessie Lake Report 


\section{Phosphorus Dynamics in Jessie Lake: Mass Flux aCross THE SEDIMENT-WATER INTERFACE}

\section{ACKNOWLEDGMENTS}

The research reported herein was conducted under contract to the Itasca County Soil and Water Conservation District, whose financial support is gratefully acknowledged. We express our gratitude to those involved in collecting the data including: Bill Nelson, Harold Goetzman, Noel Griese, Justin Watkins, Art Norton, Benjamin Erickson, Tom Fayaerts, and Maria Bergstedt. The constant interest and support of Bruce Wilson, Minnesota Pollution Control Agency, and Karl Koller, Minnesota Department of Natural Resources, are also gratefully acknowledged. Editing and production of this report was provided by Patricia Swanson. 


\section{Project Summary}

Laboratory and field measurements were conducted in Jessie Lake from May 2000 to September 2001 in order to investigate phosphorus dynamics at the sedimentwater interface. The temperature oscillations in a water column driven by the internal wave activities ranged from $15^{\circ} \mathrm{C}$ to $18^{\circ} \mathrm{C}$. The water velocities above the sedimentwater interface revealed an oscillatory flow with velocity fluctuations $\pm 5 \mathrm{~cm} / \mathrm{sec}$. High fluctuations with high energy dissipation rates were indicators of a turbulent flow at the sediment-water interface in the lake. From July 24 to September 4, the concentration of dissolved oxygen (DO) was close to zero. The anoxic conditions were disrupted by periodic mixing events induced by wind-forcing above the lake surface.

Jessie Lake sediments have relatively high water content (89.21 to $94.29 \%$ ), high porosity $\left(88.82\right.$ to $93.74 \%$ ), and low sediment density $\left(56.74\right.$ to $\left.107.41 \mathrm{~kg} / \mathrm{m}^{3}\right)$. The concentration of phosphorus-affinity metals ranged from 707.16 to $7326.0 \mathrm{mg} / \mathrm{kg}$. The mineral nutrients ranged from 139.19 to $574.98 \mathrm{mg} / \mathrm{kg}$, and the trace metals ranged from 3.51 to $87.11 \mathrm{mg} / \mathrm{kg}$. Compared to other lakes and reservoirs, Jessie Lake has relatively low phosphorus-affinity metal concentrations in sediments, represented by iron, aluminum, and calcium. The low phosphorus-affinity metal concentration resulted in a low holding capacity of phosphorus in the sediments. Dissolved reactive phosphorus in the overlying water and its release flux from the sediments were sensitive to the DO concentration in the water column. A substantial amount of dissolved reactive phosphorus was released from the sediments under the anaerobic conditions, while the phosphorus in the water column settled to the sediments under the aerobic condition. Anaerobically, the release flux of phosphorus was $16.93 \mathrm{mg} / \mathrm{m}^{2} /$ day.

The long-term simulation results indicate that if organic loading to the lake sediments continues at the rate observed in the past, the internal loading of phosphorus from the sediments to the overlying water will be doubled in the next 30 years. The reduction in the organic loading of $1 \%, 5 \%, 10 \%$ and $25 \%$ corresponds to the reduction in the phosphorus internal loading of $9.7,3.0,0.7$, and $0 \mathrm{mg} / \mathrm{m}^{2} /$ day, respectively. 



\section{TABLE OF CONTENT}



PROJECT SUMMARY........................................................................................... II

TABLE OF CONTENT.........................................................................................III

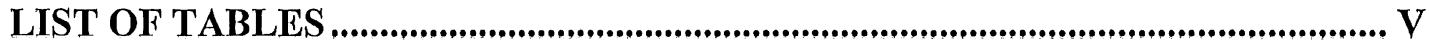

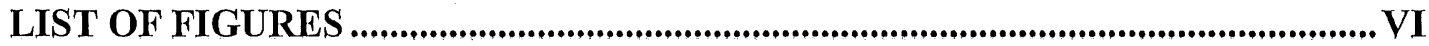

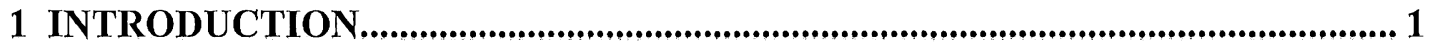

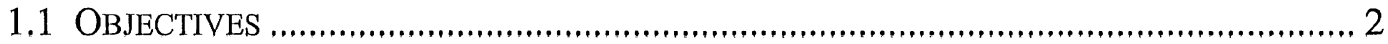

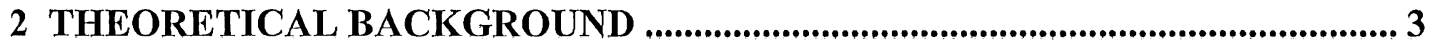



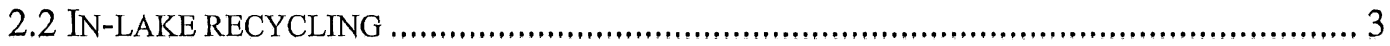

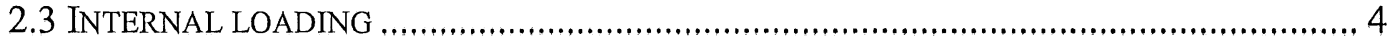

2.4 FACTORS AFFECTING PHOSPHORUS RELEASE FLUX …........................................... 5

2.4.1. Fractional composition of sediment phosphorus ............................................ 5

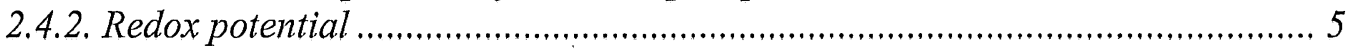

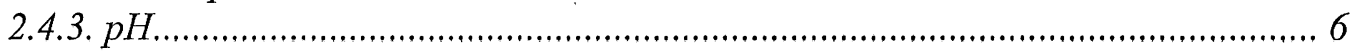

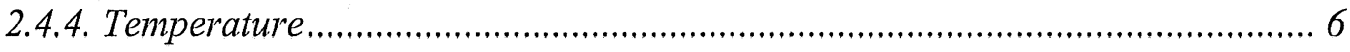

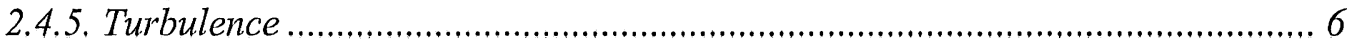

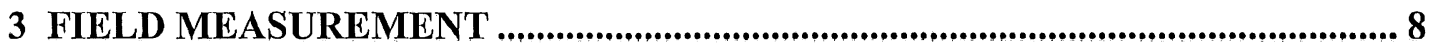

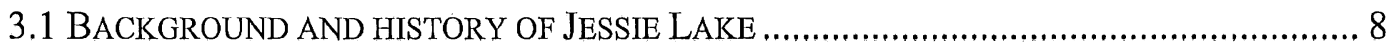

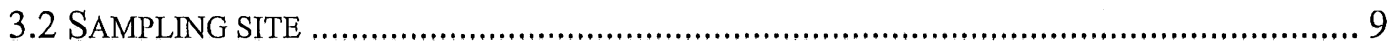



4 LABORATORY MEASUREMENT .................................................................. 13



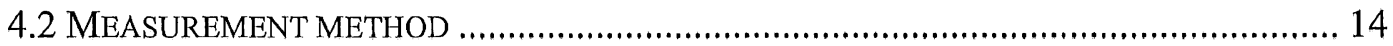

4.2.1. Physical characteristics of sediments ..................................................... 14

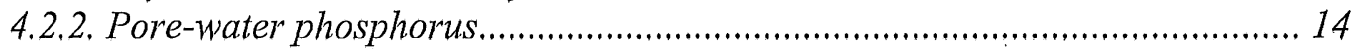

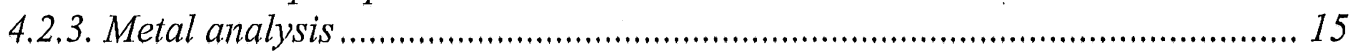

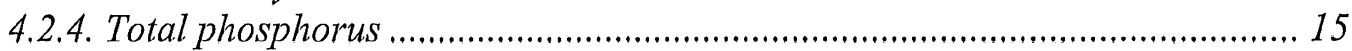

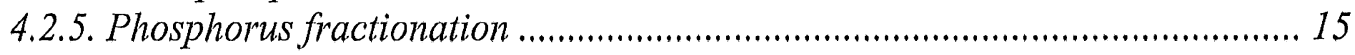



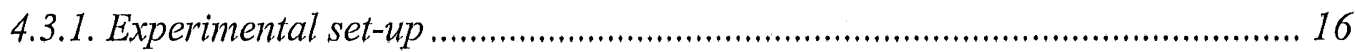

4.3.2. Experiment procedure ............................................................................... 16

5 NUMERICAL SIMULATION ............................................................................... 18

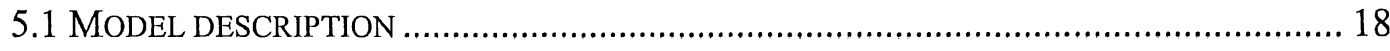








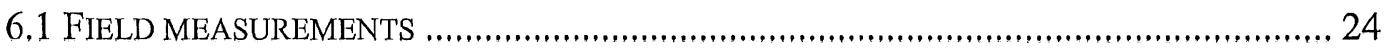

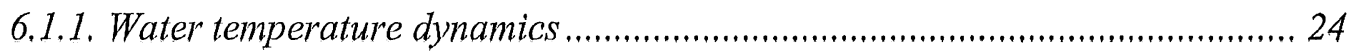

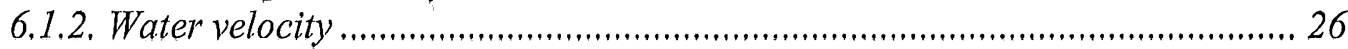

6.1.3. Microstructure measurement ............................................................................. 28

6.1.4. Dissolved oxygen dynamics above sediment-water interface ......................... 30

6.2 LABORATORY MEASUREMENT ................................................................................... 30

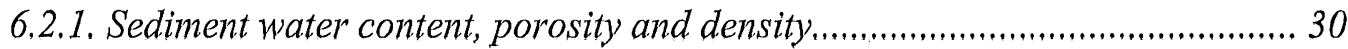

$6.2,2$. Metal concentrations in the overlying water and sediments ......................... 32

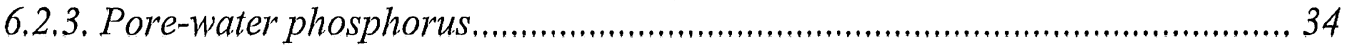

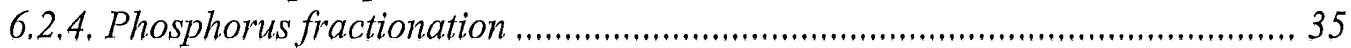

6.3 PHOSPHORUS FLUX SIMULATION .............................................................................. 39

6.3,1. General characteristics of phosphorus release processes........................... 39

6.3.2. Determinations of phosphorus release flux ...................................................... 40

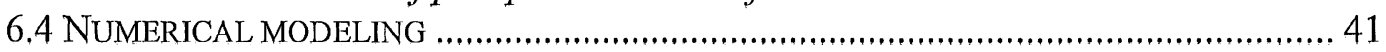

6.4.1. Model calibration....................................................................................... 41

6.4.2. Short-term simulation .................................................................................... 42

7 CONCLUSIONS AND RECOMMENDATIONS..........................................46



7.2 RECOMMENDATION FOR RESTORATION AND FURTHER STUDIES ............................ 48






\section{LIST OF TABLES}

Table 1.1 Historical summary of water quality data for Jessie Lake

Table 5.1 Sediment phosphorus model developed by Wang (1999)

Table 5.2 Sediment characteristics and transport parameters used in the simulation of Jessie Lake

Table 5.3 Estimated parameters of organic decomposition in sediments

Table 6.1 Comparison of phosphorus-affinity metals in Jessie Lake versus other aquatic sediments $(\mathrm{g} / \mathrm{kg})$

Table 6.2 Comparison of phosphorus composition between Jessie Lake and other lakes (L-P is the labile phosphorus, Fe-P is the Fe \& Al bound phosphorus, $\mathrm{Ca}-\mathrm{P}$ is the $\mathrm{Ca}$ bound phosphorus and Res-P is the residual phosphorus)

Table 6.3 Model parameters

Table 6.4 Model parameters obtained by calibration versus field measurements 


\section{LIST OF FIGURES}

Fig, 2.1 Phosphorus dynamics in a lake ecosystem

Fig. 3.1 Jessie Lake: Geographical location and monitoring site

Fig. 3.2 Sampling station at Jessie Lake. Wind speed, wind direction, water temperatures, three-dimensional water velocities, $\mathrm{DO}$, and $\mathrm{pH}$ are measured and recorded at the station.

Fig. 3.3 Self-Contained Autonomous Microprofiler in the field

Fig. 4.1 Sediment core sampler in the field

Fig, 4.2 Undisturbed sediment cores collected in Jessie Lake

Fig. 4.3 Summary of fractionation scheme

Fig. $4.4 \quad$ Experimental setup

Fig. $5.1 \quad$ Sediment phosphorus model (Wang, 1999)

Fig. 6.1 Wind speed and water temperature data measured every 6 seconds in Jessie Lake from July 24 to September 4, 2001.

Fig. 6.2 Water temperature spectra, Jul 24 to Sep 4, 2001

Fig. 6.3 East, North, and Upward water velocities measured every second in Jessie Lake from July 24 to August 14, 2001

Fig. 6.4 East, North, and Upward water velocities measured every second in Jessie Lake from July 26 to July 27, 2001

Fig. 6.5 Water temperature with water temperature gradients measured by the SCAMP in Jessie Lake on August 16, 2001, 12:30 p.m.

Fig. 6.6 Water temperature spectral densities with the estimate of the turbulent kinetic energy dissipation rates at $2.7 \mathrm{~m}$ and $11.5 \mathrm{~m}$ from the water surface in Jessie Lake on August 16, 2001, 12:30 p.m.

Fig. 6.7 pH and DO measured every 20 minutes above the sediment-water interface in Jessie Lake from Jul 24 to Sep 4, 2001. 
Fig. 6.8. Water content versus sediment depth in Jessie Lake

Fig. 6.9 Porosity versus sediment depth in Jessie Lake

Fig. 6.10 Sediment density versus sediment depth in Jessie Lake

Fig. 6.11 Metal concentrations in the overlying water above the sediment-water interface in Jessie Lake

Fig. 6.12 Metal concentrations against sediment depth in Jessie Lake

Fig, 6.13 Phosphorus concentration profiles in sediments

Fig. 6.14 Summary of phosphorus species in Jessie Lake sediments

Fig. 6.15 Total phosphorus concentration in Jessie Lake sediments

Fig. 6.16 Inorganic phosphorus concentration by chemical extraction scheme in Jessie Lake sediments

Fig. 6.17 Phosphorus species in Jessie Lake sediments

Fig. 6.18 Experiment setup with sediment cores at the laboratory

Fig. 6.19 Release processes of DRP from the sediment core to water column under laboratory conditions. The sediment cores were collected in Jessie Lake on Sep 5, 2001.

Fig. 6.20 Simulated reactive organic phosphorus concentrations of labile and refractory decomposition fraction (L-OP and R-OP), pore water and exchangeable particulate phosphorus concentrations (DP and EP).

Fig. 6.21 Simulated release fluxes of phosphorus and measured DO concentrations from August 14 to September 6, 2001, Jessie Lake

Fig. 6.22 Release flux simulated under different organic loading

Fig. 6.23 Relationship between phosphorus release flux and organic loading

Fig. 6.24 Long-term predictions of internal loading of phosphorus released from sediments to the overlying water in Jessie Lake for 30 years. The predictions include the internal loading based on current condition and five hypothetical scenarios 


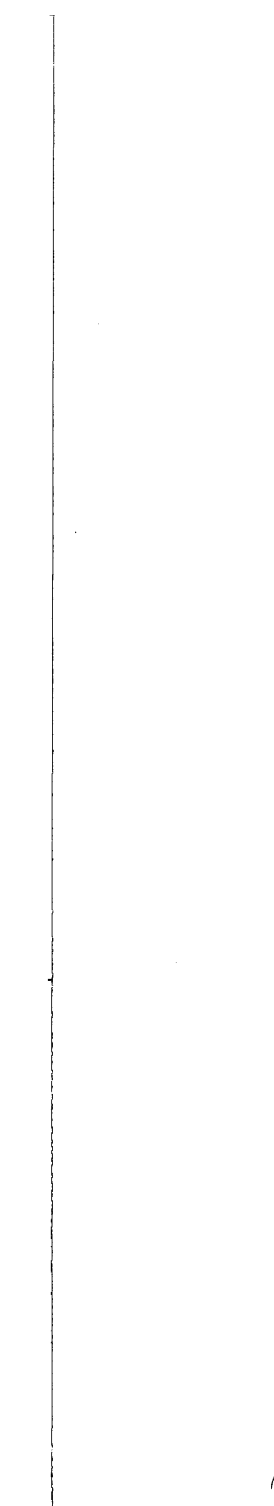




\section{INTRODUCTION}

Phosphorus is generally considered to be a major growth limiting macro nutrient in aquatic ecosystems (Jorgensen, 1983; Ishikawa et al., 1989; Fox, 1993). Cultural eutrophication of freshwater ecosystems due to anthropogenic sources of phosphorus is well documented (Wetzel, 2001; Lampert and Sommer, 1997; Stumm and Morgan, 1996; Schindler 1974). Studies have shown that in some situations eutrophication can continue even after external anthropogenic sources of phosphorus have stopped (Hu et al., 2001; Lemmin and Imboden, 1987). This has led researchers to examine other causes of eutrophication, including the significance of internal loading of phosphorus released from the sediments (Petticrew and Arocena, 2001; Blais and Kalff, 1995).

A history of nuisance algal blooms, fluctuating phosphorus concentrations and trophic level values has been documented in Jessie Lake (Reed and Watkins 1999). Because of this erratic history there is a concern that Jessie Lake is approaching a hypereutrophic state. During the last decade, phosphorus concentration has exhibited an increase of $135 \%$ over 6 years from $24 \mathrm{ug} / \mathrm{L}$ in 1992 to $57.3 \mathrm{ug} / \mathrm{L}$ in 1998 (Reed and Watkins, 1999), placing Jessie Lake in the $90^{\text {th }}$ percentile of total phosphorus concentration in its eco-region (Heiskary and Wilson, 1988). The Carlson Trophic Status evaluated in terms of Secchi disc, phosphorus, and chlorophyll-a concentrations suggested that Jessie Lake ranged in the mesotrophic class in 1992 and in the eutrophic class in 1998 (Redd and Watkins, 1999). The increasing deterioration of water quality in the lake has impacted its ecological conditions, biological species, recreation potential and property value. During the summer of 1998 a fish kill occurred due to the low oxygen levels within the lake.

The Clean Water Partnership is a two-phase program that was developed to address water quality and pollution problems in Minnesota (MPCA, 1995). This program allows local agencies and groups to receive state funding and specialized assistance from state experts. The phases are awarded separately with the first phase addressing resource investigation, a diagnostic study and implementation plan, and the second phase implementing best management practices developed from the Phase I plan. A Phase I grant application for Jessie Lake was submitted in 1999 and granted by the Minnesota Pollution Control Agency (MPCA). Prior to the initiation of Phase I, the Itasca Soil and Water Conservation District (ISWCD) had obtained water quality measurements in 1998 and 1999, which became the foundation for Phase I sampling. Phase I was initiated in the year 2000 and is a cooperative project that includes: ISWCD, Chippewa National Forest (CNF), Minnesota Department of Natural Resources (MNDNR), MPCA, the Jessie Lake Watershed Association (JLWA), University of Minnesota, St. Anthony Falls Laboratory (SAFL), Natural Resources Research Institute (NRRI) at Vermillion, and the Northern Experimental Station- Grand Rapids (USFS). 


\subsection{Objectives}

The objectives of this study are to address the following:

a) Water temperature, dissolved oxygen, fluid velocity, and $\mathrm{pH}$ dynamics near the sediment-water interface;

b) Distribution of phosphorus and metals in the sediments of Jessie Lake; and

c) Formulation of a conceptual model for the dynamics of phosphorus in the sediments of Jessie Lake. 


\section{THEORETICAL BACKGROUND}

\subsection{External loading}

Several sources of phosphorus are present in a lake ecosystem. Natural inorganic phosphorus originates from the natural weathering and solution of phosphate minerals. The phosphorus is primarily apatite transferred through tributary streams and natural runoff, which in essence constitutes phosphorus loading. Usually, the source is very low except in volcanic regions in which bedrock is rich in phosphorus. In virgin, noncultivated soils runoff is strongly absorbed by soil particles and generally does not yield any phosphorus. However, soil erosion and arable fertilization activities create enriched phosphorus drainage and runoff waters which lead to phosphorus diffusion sources. Direct discharges of phosphorus from industrial and domestic activities, called the point source, are rich in nutrients. This source is the most important contributor to eutrophication of many aquatic environments. Eutrophication, in general, is a natural process of aging of a lake. However, human activities usually result in higher nutrient input into aquatic environments, and can contribute to substantial acceleration of the aging process. This, in turn, leads to water quality deterioration, often accompanied with symptoms of unexpected algal blooms, nuisance smells and odors, and de-oxygenation by the decomposition of dead algae. The primary reason for this process is the considerable addition of nutrients, which results in increased fertility, and thus encourages the proliferation of algae and hydrophytes.

\subsection{In-lake recycling}

Phosphorus, which enters lakes through atmospheric deposition, runoff and stream discharge, may recycle in the lake ecosystem among the overlying water, sediments, and organisms as shown in Fig. 2.1. The fate of phosphorus is closely linked with the biological, geochemical, and mixing processes. Dissolved phosphorus particles deposit onto the lake bottom and interact with organic particles and cations. In the surface zone of a lake such as at the epilimnion, where a substantial amount of algae exists, a greater part of phosphorus is biologically transferred into organic phosphorus. The formed organic particles finally settle onto sediments (Hakanson and Jansson, 1983).

At the lake bottom, deposited organic phosphorus is either biologically decomposed into inorganic phosphorus by bacteria or partially buried into deep sediments by sedimentation. The behavior of regenerated inorganic phosphorus in sediments may be partitioned between mineral particles and sediment pore water or directly incorporated into apatite and hydroxide minerals in the higher $\mathrm{pH}$ environment. The fate of the phosphorus deposited on the bottom may be fixed in sediments or released backward into 
the overlying water, depending on physical and chemical characteristics of the sedimentwater interface in lakes.

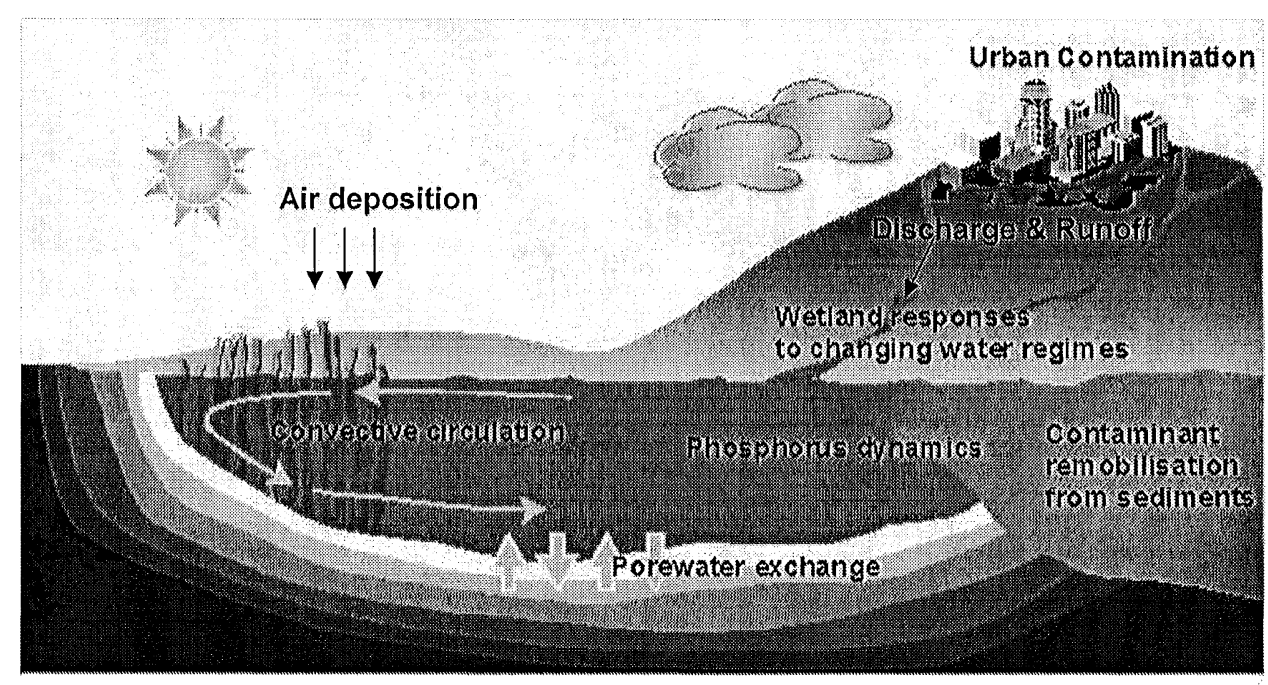

Fig. 2.1. Phosphorus dynamics in a lake ecosystem

\subsection{Internal loading}

Phosphorus may be released from the sediment to overlying water through transport processes (such as diffusion) and bioturbation. During a period of heavy input loads, phosphorus may accumulate in lake sediments. But after the external loading is considerably reduced during eutrophication control, there is a release of phosphorus from sediments, especially when the sediment-water interface is under anaerobic conditions. This phenomenon has been observed in both field and laboratory studies and may prevent or delay the efficiency of restoration measures (Bostrom et al., 1985; Sondergaard et al., 1993; 1996). In some lakes and reservoirs located in temperate regions, it has been shown that the flux of phosphorus released from sediments to the overlying water is comparable to the external loading (Ishikawa et al., 1989).

Decomposition of organic matter in sediments has been reported to be a driving force for the release of phosphorus from sediments to overlying water (Boers, 1988; Di Toro and Fitzpatrick, 1993). The organic matter, supplied by settling of dead biomass, is used as an energy source by sediment-living bacteria and fungi through their metabolism activities. One product, ortho-phosphorus, is regenerated from the particulate organic matter during metabolism activity and acts as a primary source for the release of sediment phosphorus. 
In addition, lake sediments can act not only as a sink but also a source for phosphorus. Studies have demonstrated that phosphorus has a strong affinity to oxide iron and aluminum. Reduction and oxidation (redox) of these metals in sediments regulate the dynamics of phosphorus. The mechanisms of phosphorus mobilization are explained by the reductions of insoluble metal oxides such as Fe(III) to soluble Fe(II) in sediments or water whereby phosphorus bound to Fe(III) or adsorbed to iron complexes is returned to solution when system redox potentials change from aerobic to anaerobic conditions. Increased soluble phosphorus together with phosphorus regenerated from the organic materials result in a high concentration of phosphorus in the interstitial water. The increase in concentration gradient between the sediment pore water and overlying water drives phosphorus flux into the overlying water.

\subsection{Factors affecting phosphorus release flux}

\subsubsection{Fractional composition of sediment phosphorus}

Generally, phosphorus components in sediments are composed of inorganic and organic phosphorus that may be mobilized through chemical and biochemical reactions. These compositions can be further-subdivided into much detailed fractions according to their mobilization and methods of extraction. Studies have demonstrated that one or more of these phosphorus fractions are associated with phosphorus release (Hosomi et al,, 1981; Psenner, 1984). Additionally, patterns of phosphorus release under different environmental conditions can be explained by differences in the fractional composition of phosphorus (Bostrom, 1982, 1984).

Fractionation schemes (Williams et al., 1976; Hieltjes and Lijklema, 1980) have been used to separate and identify each phosphorus fraction based on the chemical fraction. The fractions of phosphorus include organic phosphorus, apatite phosphorus, and nonapatite phosphorus (loosely-bound phosphorus; (Fe+Al)-bound phosphorus; and $\mathrm{Ca}$ bound phosphorus, corresponding to $\mathrm{NH}_{4} \mathrm{Cl}, \mathrm{NaOH}$ and $\mathrm{HCl}$ extractions).

Tandon et al. (1968) demonstrated that the exchangeable phosphorus in fertilized soil was associated with the $\mathrm{Fe}$ and $\mathrm{Al}$ bound-fraction. Furumai (1989) demonstrated that most of the exchangeable phosphorus in the sediments is associated with $\mathrm{Fe}$ and $\mathrm{Al}$ bound phosphorus, in which the $\mathrm{NH}_{4}$ fraction has a higher exchangeable potential than the NaOH fraction. Exchangeable phosphorus involved those associated with the Langmuir-type exchange reaction between liquid phase and solid phase and related directly to phosphorus release in response to changes in both aerobic and anaerobic conditions as well as different $\mathrm{pH}$ levels.

\subsubsection{Redox potential}

Among the environmental factors affecting phosphorus dynamics, system redox potential is acknowledged as a major factor regulating phosphorus mobilization in sediments and release fluxes to the overlying water (Holdren and Armstrong, 1980; Nakajima, 1983). The mechanisms are considered to be chemical processes of oxidation 
and reduction of $\mathrm{Fe}, \mathrm{Mn}$, and other metals. Because phosphorus has a strong affinity to interact with the oxides of such metals, the mobilization and dynamic behavior of phosphorus in sediments are closely related to these reduction and oxidation processes.

The effects of redox conditions at the sediment-water interface on the phosphorus dynamics have been studied intensively in temperate regions (Mortimer, 1941, 1942, 1971; Fillos and Swanson, 1975; Furumai and Ohgaki, 1989), A substantial amount of phosphorus released from sediments was observed under anoxic conditions. It was noted that with decreasing redox potential, $\mathrm{Mn}$ was first released, followed by $\mathrm{Fe}$, and then phosphorus. Usually the reduction of $\mathrm{Fe}(\mathrm{III})$ takes place at redox potential around $200 \mathrm{mV}$, which corresponds to a DO concentration of approximately $0.1 \mathrm{mg} / \mathrm{L}$. However, when the DO falls below $1 \mathrm{mg} / \mathrm{L}$ at the sediment-water interface, there is a decrease in redox potential in the upper few millimeters of sediment. Correspondingly, mobilization and release of $\mathrm{Fe}$ and $\mathrm{Mn}$ take place.

\subsection{3. $\mathrm{pH}$}

An important factor regulating dynamics of phosphorus in sediments (Boers, 1991) is $\mathrm{pH}$. A high $\mathrm{pH}$ in the water column may be induced by enhanced photosynthetic activities. This process reduces carbon dioxide from the water and changes the $\mathrm{CO}_{2} /$ $\mathrm{HCO}_{3}{ }^{-} / \mathrm{CO}_{3}{ }^{2-}$ equilibrium that controls $\mathrm{pH}$. In eutrophic lakes, the algae may significantly reduce $\mathrm{CO}_{2}$ and increase the $\mathrm{pH}$ as high as 10 (Boers, 1990). However, when the hypolimnion becomes anoxic, the $\mathrm{pH}$ decreases due to $\mathrm{CO}_{2}$ production (Golterman, 1995).

The sorption of phosphorus is strongly independent on $\mathrm{pH}$ (Lijklema, 1980). High $\mathrm{pH}$ causes the desorption of phosphorus from $\mathrm{Fe}$ (III) hydroxides, resulting in a release of phosphorus from sediments. Lijklema et al., $(1977,1993)$ demonstrated that the sorption of dissolved phosphorus on inorganic particulates is a function of $\mathrm{pH}$ as well.

\subsubsection{Temperature}

Temperature affects primarily kinetic processes occurring within the phosphorus recycle. Temperature enhances the rate of chemical and biochemical processes, bioactivities, and molecular thermodynamics associated with diffusion and sorption processes. The biological decomposition of organic phosphorus is highly temperaturedependent. The temperature also influences release patterns of phosphorus (Kelderman et al., 1982). The impact of temperature on phosphorus release flux is also dependent on chemical, redox, and mixing conditions of the lakes (Boers et al., 1988, Holdren and Armstrong, 1980; Psenner, 1984).

\subsubsection{Turbulence}

Water above the sediment-water interface is often dynamic due to the turbulence activities that are frequently induced by Seiche motions. Turbulent mixing greatly influences the transport of dissolved phosphorus in the sediments (Petr, 1977). Field and 
laboratory measurements have indicated that water mixing at the sediment-water interface significantly enhances the release of phosphorus (Holdren and Armstrong, 1980; Ryding and Forsberg, 1977). 


\section{FIELd MEASUREMENT}

\subsection{Background and history of Jessie Lake}

Jessie Lake is positioned in the Rainy River Basin, which flows to the north and discharges into Hudson Bay, The lake is polymictic with a northwest-southeast orientation (MNDNR 1999), In 1967 there were 25 homes (12 seasonal) within the watershed; this number had almost tripled by 1998. Presently there are approximately 105 homes and four resorts within the Jessie Lake watershed with approximately $80 \%$ seasonal (ISWCD 2000). The watershed is 6,408-hectares with approximately $40 \%$ National Forest Land, 11\% belonging to the State of Minnesota and 2.5\% belonging to Itasca County (Reed and Watkins, 1999). Having 50\% of the watershed in public lands provides a unique opportunity for extensive management and land use planning within the watershed.

The Carlson Trophic Status Index is used to measure trophic status and thus water quality within the State of Minnesota (MPCA 2000; Carlson 1977). This index uses Secchi disc, phosphorus and chlorophyll- $a$ measurements to rate lakes according to trophic status. In 1998 the Carlson Trophic Status Index (TSI) for Jessie Lake was 57, which placed it in the eutrophic class. Previous studies yielded TSI levels of 49.7 (1986) and 42.9 (1992), placing Jessie Lake in the mesotrophic class (Reed and Watkins, 1999, MPCA, 2000). There is much concern among regulating agencies and lake residents that the trophic status may be declining, or at best unstable. Table 1 below summarizes recent history of Jessie Lake with several water quality indicators as well as the Carlson Trophic Index for that year.

Jessie Lake has experienced nuisance algal blooms and a decrease in water clarity intermittently over the years as reported by residents living on the lake. Jessie Lake is important as a recreational site and fishery for tourists and local residents. It is considered one of the better walleye fisheries in the area and has been placed on "Minnesota's Top 100 Walleye Lakes List published by the Hunting and Fishing Library. In the past Jessie Lake has been known as a good natural spawning lake for walleye (MNDNR 1999). During the last decade walleye recruitment within the lake has declined, and the lake now has greater dependence on walleye stocking. Composition of the fisheries within the lake could also change from one of cool-water species such as walleye to less desirable warm water species (Kohler and Hubert, 1999). Other recreational activities on the lake, such as water-skiing and swimming, may also be affected by declining water quality. Lakeshore residents are concerned that property values could be adversely affected by a decrease in water quality. All cooperators are concerned that erratic fluctuations of phosphorus concentrations and TSI values are an indicator that Jessie Lake is moving into a hypereutrophic status. 
Table 1. Historical summary of water quality data for Jessie Lake

\begin{tabular}{|c|c|c|c|c|}
\hline Year & $\begin{array}{c}\text { Total Phosphorus } \\
(\mathrm{ug} / \mathrm{l})\end{array}$ & $\begin{array}{c}\text { Secchi Disc } \\
(\mathrm{m})\end{array}$ & $\begin{array}{c}\text { Chlorophyll-a } \\
\text { (ug/l) }\end{array}$ & $\begin{array}{c}\text { Carlson's Trophic } \\
\text { Index (TSIS) }\end{array}$ \\
\hline $1981^{\mathrm{a}}$ & $40^{(1)}$ & $1.3^{(1)}$ & $25^{(1)}$ & \\
\hline $1982^{\mathrm{a}}$ & $70^{(1)}$ & $1.8^{(1)}$ & $17.6^{(1)}$ & 49.7 \\
\hline $1986^{\mathrm{b}}$ & $26^{(13)}$ & $2.3^{(1)}$ & $7.1^{(11)}$ & 42.9 \\
\hline $1992^{\mathrm{a}}$ & $26^{(5)}$ & $4.3^{(6)}$ & $4.7^{(4)}$ & \\
\hline $1995^{\mathrm{c}}$ & & $2.5^{(11)}$ & & \\
\hline $1996^{\mathrm{c}}$ & & $1.9^{(5)}$ & & \\
\hline $1997^{\mathrm{c}}$ & & $2.0^{(10)}$ & & 57 \\
\hline $1998^{\mathrm{d}}$ & $59^{(7)}$ & $1.6^{(26)}$ & $16.2^{(7)}$ & \\
\hline
\end{tabular}

a. STORET DATA (United States Environmental Protection Agency)

b. Phosphorus and the Trophic State of Jessie Lake (Goetzman, 1987)

c. Water clarity data collected by volunteers.

d. Jessie Lake Assessment Report (data collected in 1998, Reed and Watkins, 1999)

$(n)=$ number of measurements taken in a given year

The purpose of this study is to determine where the phosphorus influx is occurring. There is concern among agencies and residents that the unstable phosphorus and TSI values are caused by sedimentation from tributaries and cultural eutrophication (Marsden, 1989). Another source of phosphorus may exist in the form of internal phosphorus loading. In 1998, a dry year with few storm events in the area caused Jessie Lake to stratify, which it rarely does, due to its polymictic nature (Reed and Watkins, 1999). The hypolimnion most likely became anoxic. The oxygenated microzone disappeared at the sediment-water interface and released phosphorus into the lake, creating an environment advantageous to organisms such as algae (Wetzel, 2001). When the source of phosphorus loading is determined, management plans and best management practices may be implemented to correct or reverse the eutrophication process.

\subsection{Sampling site}

Jessie Lake is a 1,760-acre lake located in northwestern Itasca County and entirely within the Chippewa National Forest. The lake is stratified with a northwest-southeast orientation with a maximum fetch of 4.0 miles and shoreline length of 9.3 miles (MNDNR, 1999). The lake has a maximum depth of $42 \mathrm{ft}$ and mean depth of $22 \mathrm{ft}$. The littoral zone $(<15 \mathrm{ft})$ is generally sandy and accounts for $26 \%$ of the surface area. There is one public access located on the southeast side of the lake. The average elevation of Jessie Lake is $1,324.6 \mathrm{ft}$ mean sea level (msl), with a recorded range from 1,327.00 to $1,323.57 \mathrm{ft}$ msl. Monitoring equipment was positioned in the deepest area of the lake 
located in the northwest corner (Fig. 3.1), and substrate in this area was found to consist mostly of muck. Several sediment core samples were taken at this site.

The watershed of Jessie Lake is 15,834 acres and is within the larger Rainy River watershed, which flows north and empties into Hudson Bay. The watershed consists mostly of forest $(60 \%)$ and wetland $(24 \%)$, with some agricultural land (9\%). Over 100 private residences and four resorts are located within the Jessie Lake watershed. Most of the homes are along the Jessie Lake shoreline, or within a short vicinity of the lake (Reed and Watkins 1999). Weather data recorded from 1961 to 1990 show the area receives an annual rainfall average of 27.54 inches with an average annual temperature of $38.8^{\circ} \mathrm{F}$ and a growing season of 116 days.



Fig. 3.1. Jessie Lake: Geographical location and monitoring site

\subsection{Measuring equipment}

The lake water temperatures were measured every 6 seconds from the lake surface to the 12-m depth. The probes are metal-coded thermistors with a time constant of $2 \mathrm{sec}$. Before installation, the probes were calibrated in a water bath. The relative accuracy, the difference between successive measurements by the same probe, was $0.005^{\circ} \mathrm{C}$. A data logger installed on a small raft recorded the water temperatures from July 24 to September 4, 2001 (Fig. 3.2). A wind anemometer, installed on the raft $80 \mathrm{~cm}$ above the lake surface, measured the wind speed every 6 seconds for the same time intervals as the water temperatures. 


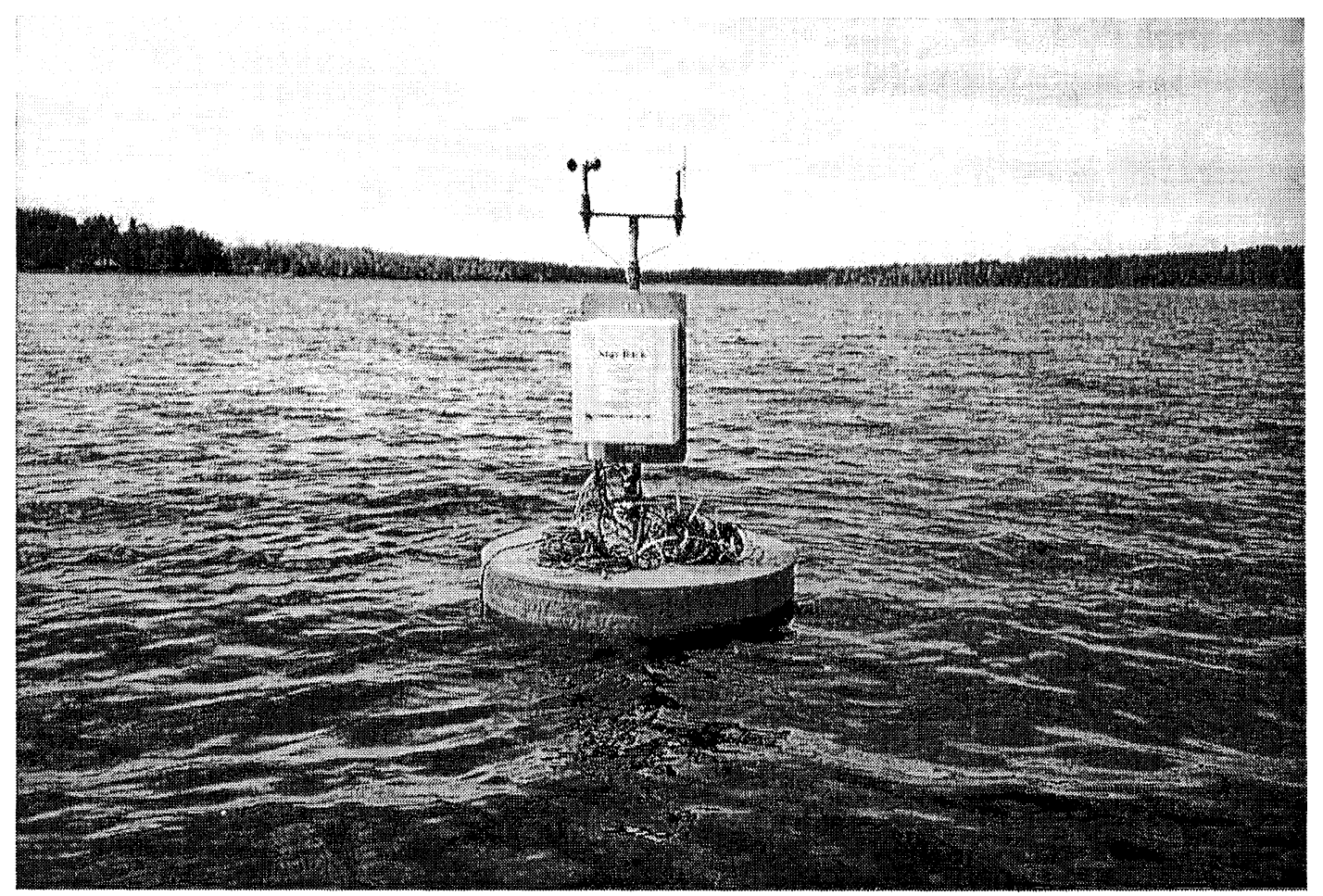

Fig. 3. 2. Sampling station at Jessie Lake. Wind speed, wind direction, water temperatures, three-dimensional water velocities, $\mathrm{DO}$, and $\mathrm{pH}$ are measured and recorded at the station.

A single-point acoustic-Doppler velocity probe with a compass and tilt sensor was used for the high precision measurement of the three-component fluid velocities above the sediment-water interface. The data were recorded every second by the processor enclosed in the underwater canister. A diver positioned the probe on the sloping boundary so that only a steam and acoustic sensor was exposed to fluid motion. The sampling volume of the probe was located about $20 \mathrm{~cm}$ above the sediment-water interface.

The Self-Contained Autonomous Microprofiler (SCAMP) was used to measure and record small-scale (from a meter to a tenth of a millimeter) fluid motions and properties in the water column (Fig. 3.3). On deployment, the microprofiler descends at $0.1 \mathrm{~m} / \mathrm{s}$, while collecting temperature data at a rate of $100 \mathrm{~Hz}$ from two pairs of sensors positioned $25 \mathrm{~mm}$ apart. In addition to the water temperature, the microprofiler measures pressure and elapsed time so that the vertical position of the probe in the water column is available. 


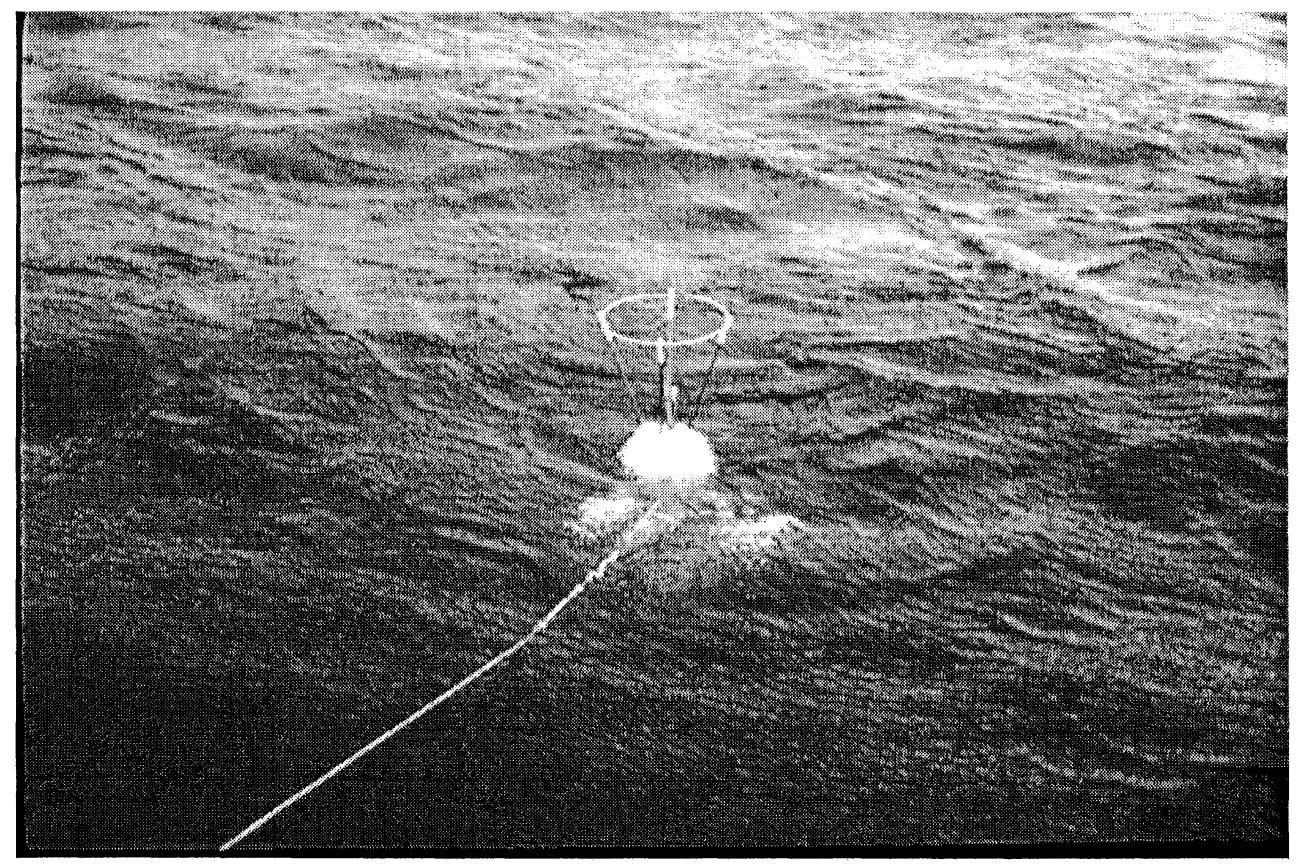

Fig. 3.3. Self-Contained Autonomous Microprofiler in the field

A water quality probe with internal recoding unit was used for the measurement of $\mathrm{DO}$ and $\mathrm{pH}$ above the sediment-water interface. The data were recorded every 20 minutes. The diver positioned the probe above the sediment-water interface so that sampling volume of the probe was located about $20 \mathrm{~cm}$ above the sediment-water interface. 


\section{LABORATORY MEASUREMENT}

\subsection{Sample collection}

Sediment samples were collected using a messenger-activated gravity core-sampler manufactured by Aquatic Research Instruments (Fig. 4.1). The collected sediment cores (Fig, 4.2) were kept in ice-boxes at $4{ }^{\circ} \mathrm{C}$ and immediately transported to the laboratory for chemical analysis. In the laboratory, collected sediment cores were treated individually for different measurement and experimental purposes.

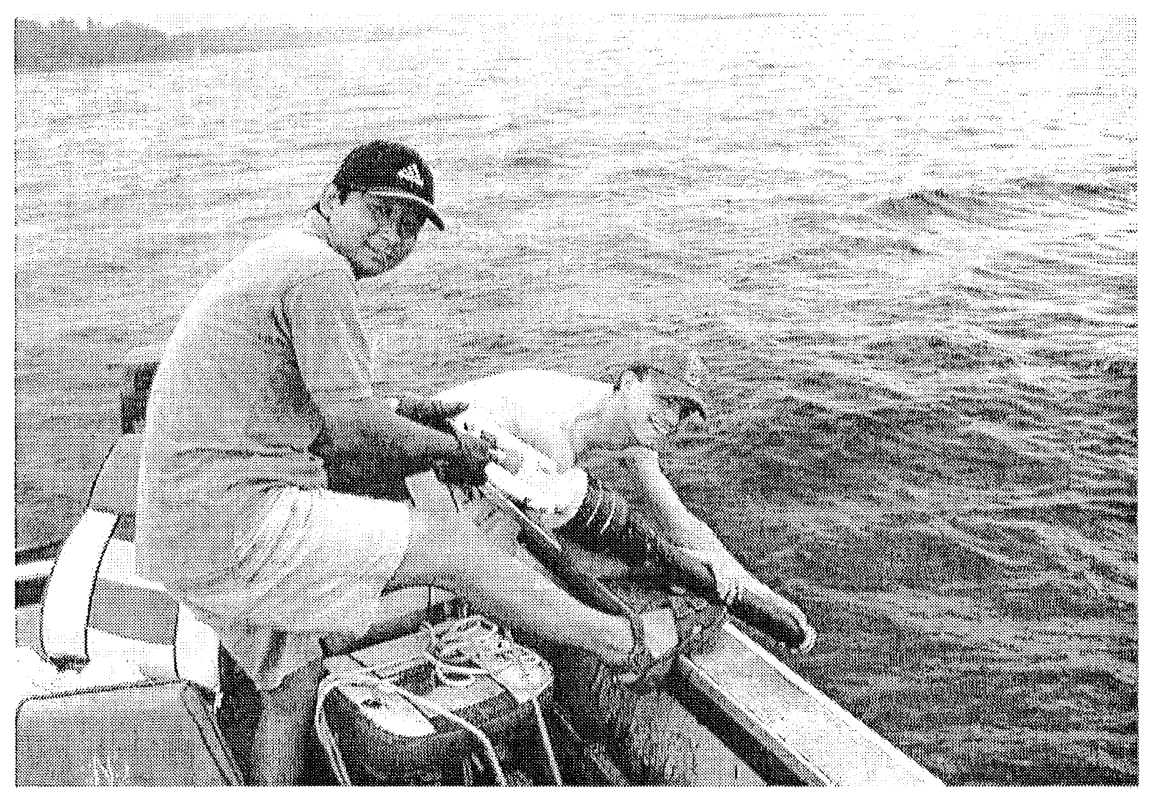

Fig. 4.1. Sediment core sampler in the field 

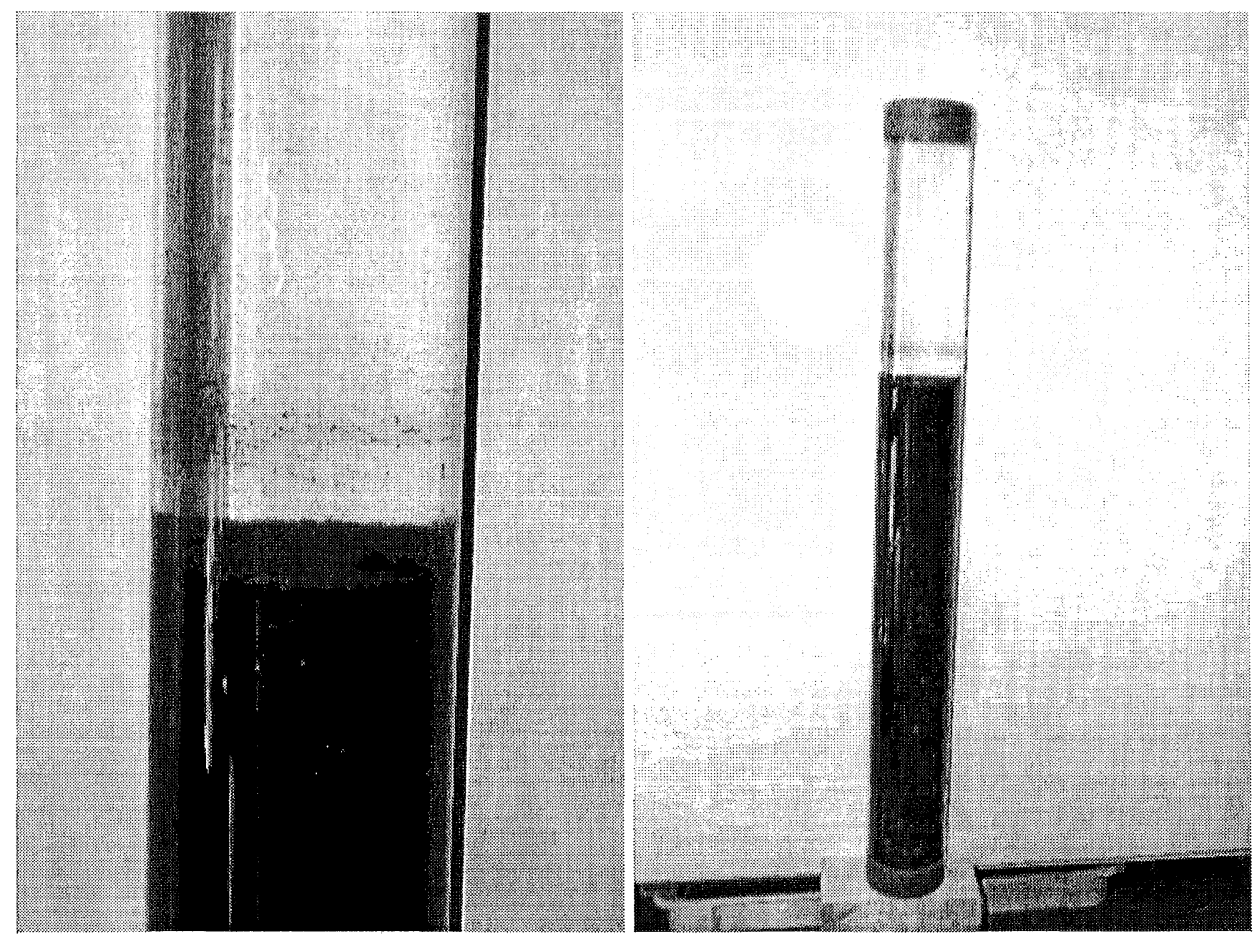

Fig. 4.2. Undisturbed sediment cores collected in Jessie Lake

\subsection{Measurement method}

\subsubsection{Physical characteristics of sediments}

Water contents, porosities, and densities are measured in the collected sediments. The sediment cores, collected in Jessie Lake, were sliced into small cylinders of $1 \mathrm{~cm}$ vertical thickness. Sliced wet sediments were weighted, and then dried in an oven at $105{ }^{\circ} \mathrm{C}$ for six hours. After cooling down in a desiccator to room temperature, the dried samples were weighed. The water content was obtained by $\frac{\text { (total wet weight - dry weight) }}{\text { total wet weight }}$. In this method, it is assumed that lake sediments are saturated with only water and that the mass and volume of gases are negligible. Because the volumes of total wet solid can be roughly determined according to the diameter and thickness of sliced sediment cores, the porosity can be estimated by $\frac{\text { pore water volume }}{\text { total sample volume }}$.

\subsubsection{Pore-water phosphorus}

Collected sediment cores were sliced into small cylinders of about $1 \mathrm{~cm}$ vertical thickness. The sliced sediment samples were immediately centrifuged at $3000 \mathrm{rpm}$ for 20 minutes to separate the pore water from sediment particles. The pore water was then passed through a $0.45 \mu \mathrm{m}$ polycarbonate membrane and the dissolved phosphorus 
concentration was measured using spectrophotometer at $880 \mu \mathrm{m}$ according to the Ascorbic Acid Method (Eaton et al., 1995).

\subsubsection{Metal analysis}

The sediment core samples used for metal analysis and phosphorus fractionation were sliced into small cylinders with $1 \mathrm{~cm}$ thickness at different depths. The sliced samples were then dried under forced air at $36^{\circ} \mathrm{C} / 97^{\circ} \mathrm{F}$, and grinded in a mortar. Prepared sediment samples were stored in a desiccator. The analysis of metals was conducted by the Research Analytical Laboratory, University of Minnesota. After passing through plastic sieves, metals were extracted by shaking $3 \mathrm{~g}$ of sediment samples in a $30 \mathrm{~mL}$ of 1 $\mathrm{N} \mathrm{HNO}_{3}$ for 1 hour. The supernatants were centrifuged and then analyzed for $\mathrm{Fe}, \mathrm{Al}, \mathrm{Mn}$, $\mathrm{Cu}, \mathrm{Zn}, \mathrm{Cd}, \mathrm{Ni}, \mathrm{Pb}, \mathrm{Cr}$ and other metals by Inductively Coupled Plasma Emission Spectrometry (ICP-AES) (Dancer et al., 1998).

\subsubsection{Total phosphorus}

The sediment cores were pre-treated as described in Section 4.2.3 to prepare fine powder sample. The analysis of total phosphorus was conducted by the Research Analytical Laboratory, University of Minnesota. After sieving through a $1.8 \mathrm{~mm}$ sieve, $0.5 \mathrm{~g}$ of the sediment samples were digested with a $10 \mathrm{~mL}$ concentrated $\mathrm{HNO}_{3}$ in a 100 $\mathrm{mL}$ Teflon lined vessel. The vessels were heated for $5.5 \mathrm{~min}$ to $175^{\circ} \mathrm{C}$ and then held at $175-180^{\circ} \mathrm{C}$ for $4.6 \mathrm{~min}$. The digests were diluted to a final volume of $40 \mathrm{~mL}$, centrifuged and analyzed for total phosphorus by Inductively Coupled Plasma Emission Spectrometry (ICP-AES) (Dancer et al., 1998).

\subsubsection{Phosphorus fractionation}

The fractionation of inorganic phosphorus was performed according to the chemical extraction method (Hieltjes and Lijklema, 1980). Three categories of phosphorus with different mobile characteristics were measured. The method included two consecutive extractions for loosely bound phosphorus using a $50 \mathrm{~mL} 1 \mathrm{M} \mathrm{NH} \mathrm{N}_{4} \mathrm{Cl}$ for 2 hours. The residue was then extracted for $\mathrm{Fe}$ and $\mathrm{Al}$ bound phosphorus with a $50 \mathrm{~mL} 0.1 \mathrm{~N} \mathrm{NaOH}$ for 17 hours, followed by a final extraction for Ca bound phosphorus with a $50 \mathrm{~mL} 0.5 \mathrm{~N}$ $\mathrm{HCl}$ for 24 hours. Each extractant was adjusted to $\mathrm{pH} 7.0$, centrifuged at $3000 \mathrm{rpm}$ for 30 minutes, and filtrated through a $0.45 \mu \mathrm{m}$ membrane. The concentration of phosphorus in each extractant was determined by Ascorbic Acid Method (Eaton et al, 1995). Organic phosphorus was estimated by the difference between total and inorganic phosphorus. The summary of the fractionation scheme is shown in Fig. 4.3 


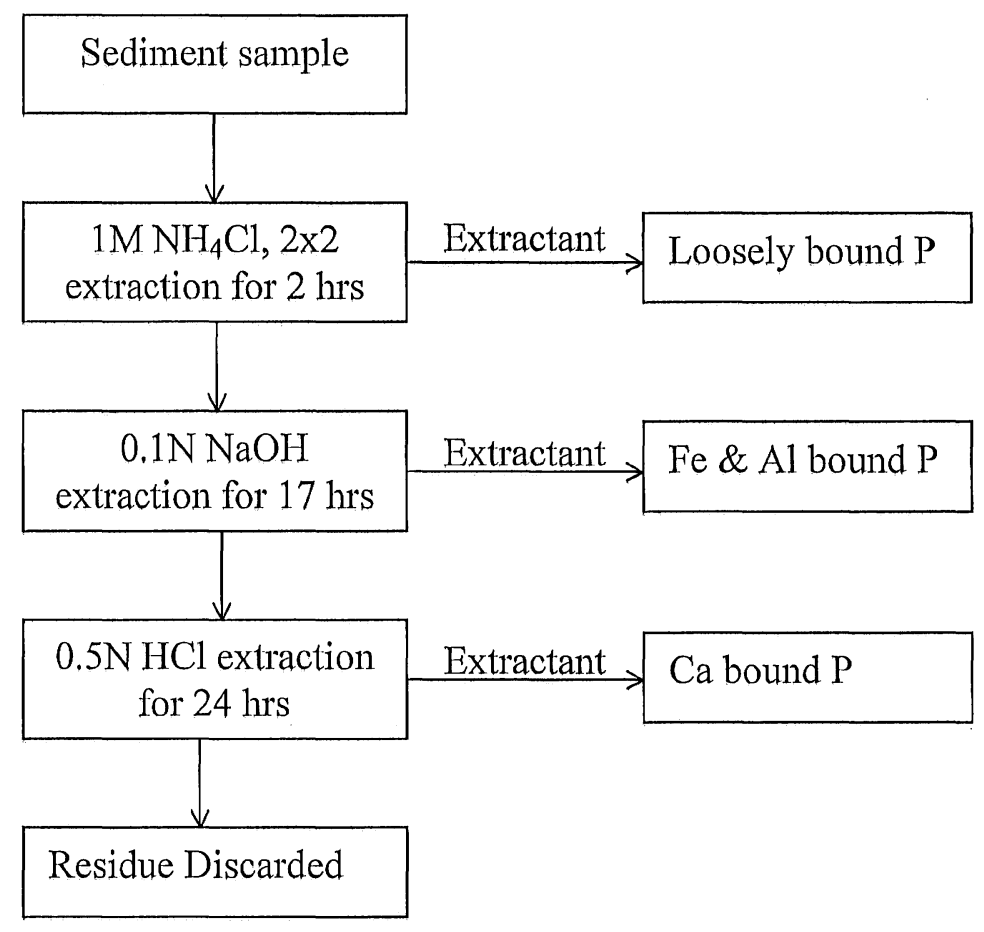

Fig. 4.3 Summary of fractionation scheme

\subsection{Phosphorus flux simulation}

\subsubsection{Experimental set-up}

A laboratory setup is provided in Fig. 4.4. The setup consists of a sediment core with a water cylinder above the core. Both sides of the reaction chamber were sealed with rubber stoppers. At the top of the cylinder, inlet and outlet tubes provided manipulation ports for the oxygenation/de-oxygenation of water above the sediment core.

\subsubsection{Experiment procedure}

Sediment cores were collected at the sampling station in Jessie Lake on September 5, 2001. Water depth at the sampling site was about $12 \mathrm{~m}$. The depth of sediment core was about $46 \mathrm{~cm}$. Two simulation systems, reassembling aerobic and anaerobic conditions, were investigated under the laboratory conditions. The lake water, which was collected at the sampling site, was filtered and loaded into the simulation system. The cylinders were wrapped with an aluminum foil to prevent algal growth. The first simulation setup was oxygenated by bubbling air, and the second simulation setup was deoxygenated by nitrogen gas. The setups were incubated at the room temperature of $22 \pm 5{ }^{\circ} \mathrm{C}$ during the experimental measurements. 


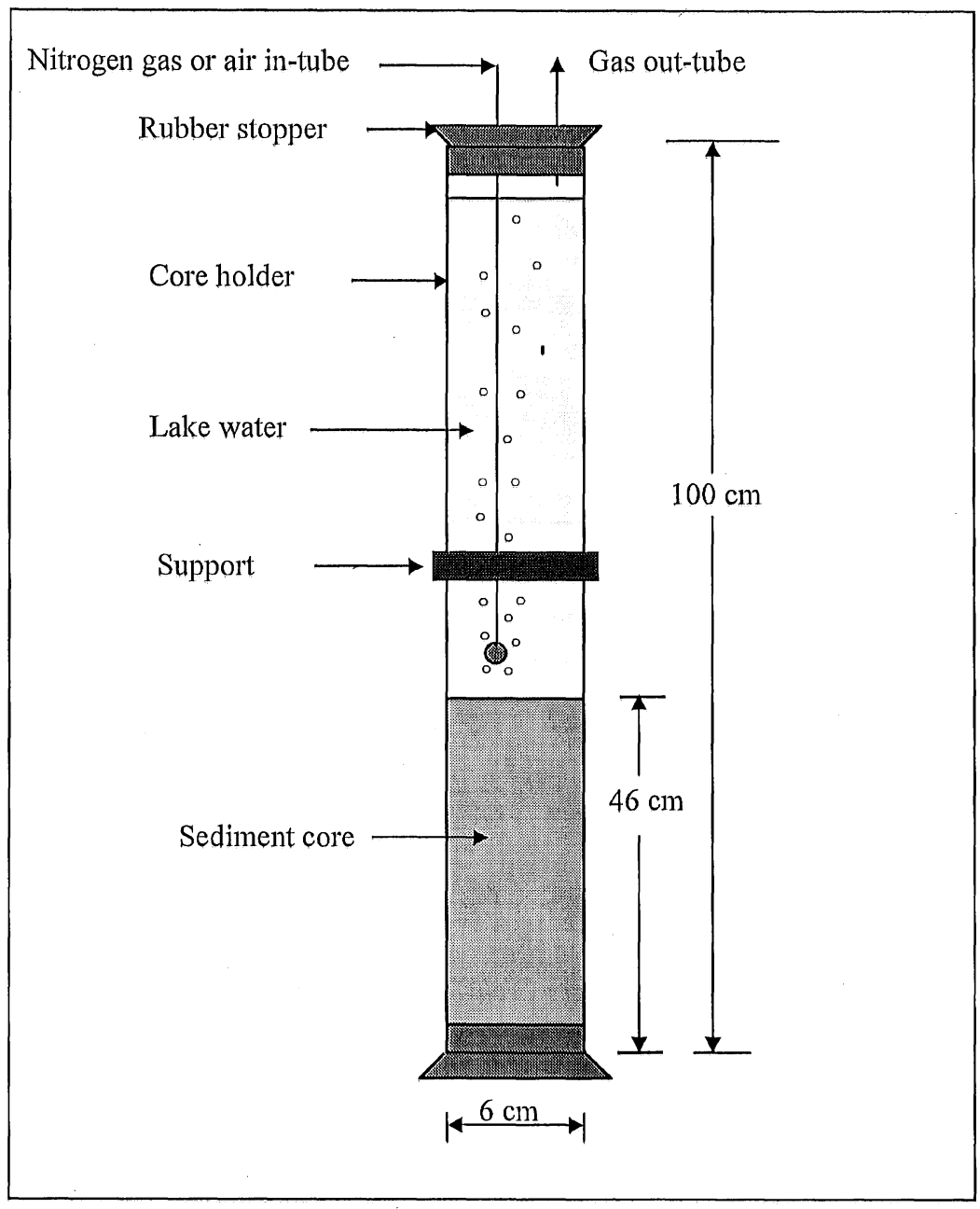

Fig. 4.4. Experimental setup

The experiments were conducted over 17 days. During the incubation period, $5 \mathrm{~mL}$ water samples were collected at different intervals. The samples were filtered and used to measure the concentrations of dissolved ortho-phosphorus (Eaton et al., 1995). The concentration of DO was monitored during the experimental procedure. 


\section{NUMERICAL SIMULATION}

\subsection{Model description}

A model consisting of six interrelated differential equations has been developed by Wang (1999) to study reactive phosphorus dynamics in aquatic sediments and to predict phosphorus release fluxes across the sediment-water interface. The model simulates processes within an active layer of $10 \mathrm{~cm}$ depth below the sediment-water interface. The active sediment layer is composed of distinct aerobic and anaerobic layers (Fig. 5.1). The equations used in the model are given in Table 5,1. The processes involved in the model include:

- the regeneration of phosphorus due to the decomposition of organic matter,

- the dynamic partitioning of phosphorus between the pore water and sediments due to sorption processes,

- the transportation of the dissolved and particulate phosphorus in sediments due to diffusion, bioturbation mixing and burial, and

- external regulating factors such as DO and temperature.

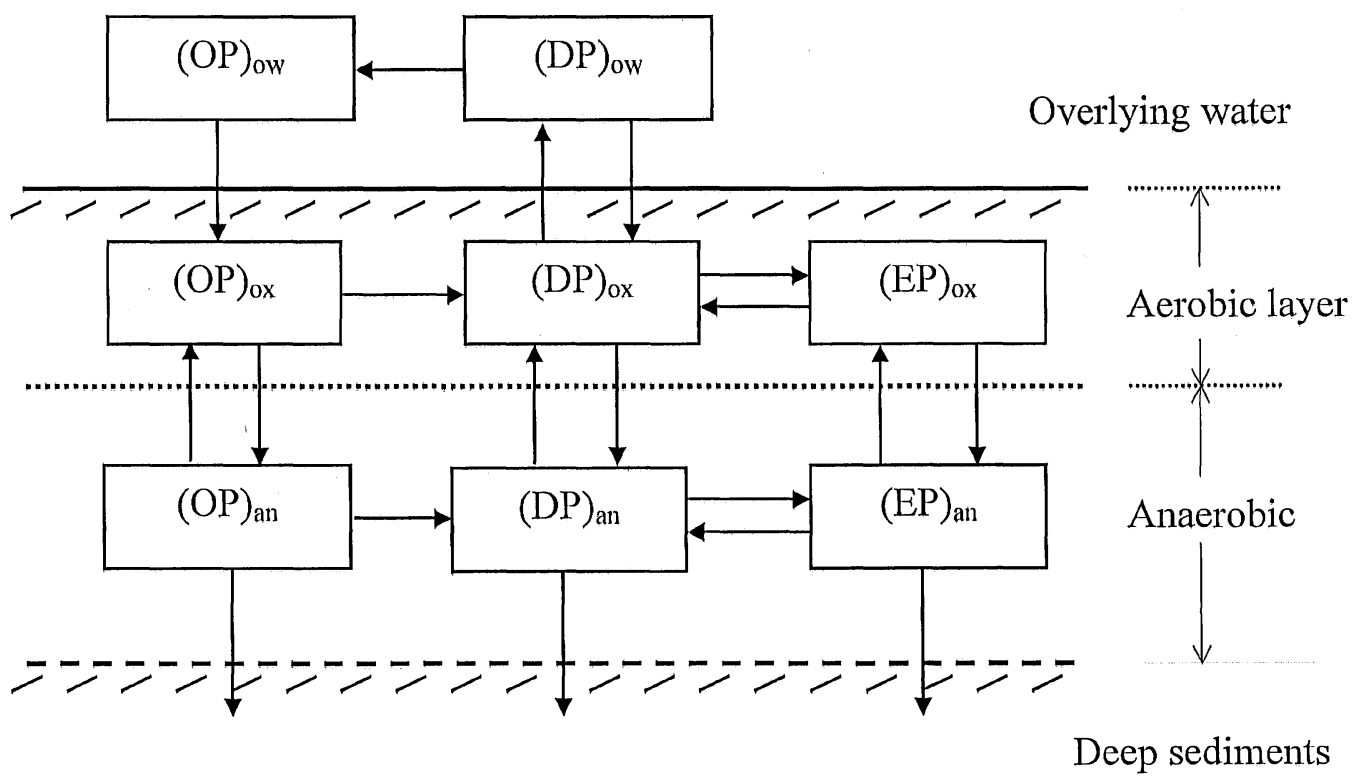

Fig. 5.1. Sediment phosphorus model (Wang, 1999) 
Table 5.1 Sediment phosphorus model developed by Wang (1999)

Dissolved phosphorus:

$$
\begin{aligned}
\delta \frac{d(D P)_{o x}}{d t}= & -2 D_{e}\left[(D P)_{o x}-(D P)_{w}\right] / \delta+2 D_{e}\left[(D P)_{a n}-(D P)_{o x}\right] / H \\
& +\delta k_{a d, o x}\left[(D P)_{o x, e}-(D P)_{o x}\right]-\omega_{w}(z)(D P)_{o x}+\delta k_{b, o x, i}(O P)_{o x, i} / \phi \\
H \frac{d(D P)_{a n}}{d t}= & -2 D_{e}\left[(D P)_{a n}-(D P)_{o x}\right] / H+H k_{a d, a n}\left[(D P)_{a n, e}-(D P)_{a n}\right] \\
& +\omega_{w}(z)\left[(D P)_{o x}-(D P)_{a n}\right]+H k_{b, a n, i}(O P)_{a n, i} / \phi
\end{aligned}
$$

with $D_{e}=D_{e}(20) \theta_{d}{ }^{(T-20)}$

$$
\begin{aligned}
(D P)_{e} & =\frac{E(E P)}{(E P)_{m}-(E P)} \\
k_{b, i} & =k_{b, i}\left(20{ }^{\circ} C\right) \theta_{b}{ }^{\left(T_{2}-20\right)} \\
\omega_{w}(z) & =\frac{\phi(\infty)}{\phi(z)} \omega(\infty)
\end{aligned}
$$

Exchangeable particulate phosphorus:

$$
\begin{aligned}
& \delta \rho \frac{d(E P)_{o x}}{d t}=-\phi(z) \delta k_{a d, o x}\left[(D P)_{o x, e}-(D P)_{o x}\right]+2 \rho D_{b}\left[(E P)_{a n}-(E P)_{o x}\right] / H \\
& -\rho \omega_{s}(z)(D P)_{o x} \\
& H \rho \frac{d(E P)_{a n}}{d t}=-\phi(H) H k_{a d, a n}\left[(D P)_{a n, e}-(D P)_{a n}\right]-2 \rho D_{b}\left[(E P)_{a n}-(E P)_{o x}\right] / H \\
& -\rho \omega_{s}(z)\left[(E P)_{a n}-(E P)_{o x}\right] \\
& \text { with } \mathrm{D}_{\mathrm{b}}=\mathrm{D}_{\mathrm{b}}(20) \frac{(\mathrm{OC})_{1}}{(\mathrm{OC})_{\text {ref }}} \frac{(\mathrm{DO})}{(\mathrm{DO})_{\text {half }}-(\mathrm{DO})} \theta_{\mathrm{m}}^{(\mathrm{T}-20)}
\end{aligned}
$$




$$
\omega_{s}(z)=\frac{1-\phi(\infty)}{1-\phi(z)} \omega(\infty)
$$

Organic phosphorus:

$$
\begin{aligned}
\delta \frac{d(O P)_{o x, i}}{d t}= & \alpha_{c, p} F_{(O M)}-\delta k_{b, o x, i}(O P)_{o x, i}-2 D_{b}\left[(O P)_{o x, i}-(O P)_{a n, i}\right] / H \\
& -\omega_{s}(z)(O P)_{o x, i} \\
H \frac{d(O P)_{a n, i}}{d t}= & -H k_{b, a n, i}(O P)_{a n, i}+2 D_{b}\left[(O P)_{o x, i}-(O P)_{a n, i}\right] / H \\
& -\omega_{s}(z)\left[(O P)_{a n, i}-(O P)_{o x, i}\right]
\end{aligned}
$$

$\mathrm{D}_{\mathrm{b}}(20)=$ effective constant of bioturbation at $20^{\circ} \mathrm{C}$ in $\mathrm{m}^{2} /$ day

$\mathrm{D}_{\mathrm{e}}=$ effective diffusion coefficient in $\mathrm{m}^{2} /$ day

$\mathrm{D}_{\mathrm{e}}(20)=$ effective diffusion constant in the pore water at $20^{\circ} \mathrm{C}$ in $\mathrm{m}^{2} /$ day

$(\mathrm{DP})_{\mathrm{ox}},(\mathrm{DP})_{\mathrm{an}}$ and $(\mathrm{DP})_{\mathrm{w}}=$ concentrations of dissolved phosphorus in aerobic, anaerobic layers and overlying water $\mathrm{g} / \mathrm{m}^{3}$, respectively,

$\mathrm{E}=$ Langmuir constant of sorption in $\mathrm{m}^{3} / \mathrm{g}$

$(E P)_{e}=$ Dissolved phosphorus concentration at sorption equilibrium in $\mathrm{g} / \mathrm{m}^{3}$

$(\mathrm{EP})_{\mathrm{m}}=$ maximum sorption capacity in $\mathrm{g} / \mathrm{kg}$

$(\mathrm{EP})_{\mathrm{ox}}$ and $(\mathrm{EP})_{\mathrm{an}}=$ concentrations of exchangeable particulate phosphorus in aerobic and anaerobic layers in $\mathrm{g} / \mathrm{kg}$, respectively

$\mathrm{F}_{(\mathrm{OM})}$ is the deposition flux of organic matter from the overlying water in $\mathrm{g} / \mathrm{m}^{2} / \mathrm{day}$

$\mathrm{H}=$ depth of anaerobic sediment layers in $\mathrm{m}$

$\mathrm{k}_{\mathrm{b}, \mathrm{i}}=$ decomposition rate constants for fraction $\mathrm{i}$ of organic matter in day ${ }^{-1}$

$\mathrm{k}_{\mathrm{ad}}=$ desorption rate constant in $\mathrm{day}^{-1}$

$(\mathrm{OC})_{1}=$ labile fraction concentrations of organic carbon in $\mathrm{g} / \mathrm{m}^{3}$,

$(\mathrm{OC})_{\mathrm{ref}}=$ reference concentrations of organic carbon in $\mathrm{g} / \mathrm{m}^{3}$,

$(\mathrm{DO})_{\text {half }}=$ half saturation constant of particle mixing for DO in $\mathrm{g} / \mathrm{m} 3$

$(\mathrm{OP})_{\mathrm{i}, \mathrm{ox}}$ and $(\mathrm{OP})_{\mathrm{i}, \mathrm{an}}=$ concentrations of $\mathrm{i}$ fraction of organic phosphorus in aerobic and anaerobic layers in $\mathrm{g} / \mathrm{m}^{3}$ 
$\mathfrak{t}=$ time in day

$\mathrm{T}=$ temperature in ${ }^{\circ} \mathrm{C}$

$\alpha_{0, \mathrm{c}}$ is the stoichiometric ratio of oxygen and carbon in $\mathrm{g} \mathrm{O} / \mathrm{gC}$

$\delta=$ depths of aerobic sediment layers in $\mathrm{m}$,

$\phi(\mathrm{z})$ and $\phi(\infty)=$ sediment porosities at depth $\mathrm{z}$ and final depth in fraction

$\theta_{\mathrm{d}}, \theta_{\mathrm{m}}$ and $\theta_{\mathrm{b}}=$ Arrhenius temperature coefficients for diffusion, mixing and decomposition, respectively

$\rho=$ sediment density

$\omega_{\mathrm{w}}(\mathrm{z})=$ burial velocity of pore water at the depth of $\mathrm{z}$ in $\mathrm{m} /$ day

$\omega_{\mathrm{s}}(\mathrm{z})=$ burial velocity of solid matter at the depth of $\mathrm{z}$ in $\mathrm{m} /$ day

\subsection{Model input}

The model input includes state parameters and external variables. The state parameters characterize sediment properties and biogeochemical processes relevant to phosphorus dynamics in sediments, The parameters include sediment porosities and densities, particulate phosphorus bioturbation coefficients, pore-water diffusion coefficients, burial coefficients, phosphorus sorption kinetic rates, non-linear partitioning constants, organic phosphorus decomposition rates and fractions, sediment oxygen consumption rate in sediments, and temperature coefficients.

The external variables are forcing functions affecting the state of the sediment-water interaction. The variables include the deposited fluxes of organic matter from the overlying water onto sediments, phosphorus and dissolved oxygen (DO) concentrations and temperature above the sediment-water interface. The variables are obtained through field measurements as discussed in Section 6.

The sediment characteristics and transport parameters used in the modeling are listed in Table 5.2. Sediment porosity and density were measured from the collected sediment cores in Jessie Lake. The values are based on the top $10 \mathrm{~cm}$ of sediments. The burial velocities of particulate sediments and pore-water were $0.5 \mathrm{~cm} / \mathrm{yr}$ (Di Toro, 2001). The effective coefficients of pore water diffusion and particulate bioturbation mixing at $20^{\circ} \mathrm{C}$ were obtained from the literature (Di Toro and Fitzpatrick, 1993; Wang, 1999). 
Table 5.2. Sediment characteristics and transport parameters used in the simulation of Jessie Lake, USA

\begin{tabular}{l|l}
\hline \multicolumn{1}{c|}{ Parameters } & \multicolumn{1}{c}{ Values } \\
\hline sediment characteristics & $71.44 \mathrm{~kg} / \mathrm{m}^{3}$ \\
\hline${ }^{1}$ Density & $92.84 \%$ \\
${ }^{1}$ Porosity & $41.0 \mathrm{mg} \mathrm{C} / \mathrm{mg} \mathrm{P}$ \\
${ }^{2} \mathrm{C} / \mathrm{P}$ ratio & $25-100 \mathrm{mg} \mathrm{C} / \mathrm{mg} \mathrm{Chl} a$ \\
${ }^{2} \mathrm{C} / \mathrm{Chl} a$ ratio & \\
& \\
Transport parameters & $1.37 \times 10^{-5} \mathrm{~m} /$ day \\
${ }^{2}$ Burial rate coefficients & $2.0 \times 10^{-4} \mathrm{~m}^{2} /$ day \\
${ }^{3}$ Effective diffusion rate coefficient at $20^{\circ} \mathrm{C}$ & 1.08 \\
${ }^{4}$ Temp. coefficient for diffusion & $5.0 \times 10^{-5} \mathrm{~m}^{2} /$ day \\
${ }^{3}$ Effective mixing rate coefficient at $20^{\circ} \mathrm{C}$ & 1.117 \\
${ }^{4}$ Temp. coefficient for mixing & $50 \mathrm{~g} / \mathrm{m}^{3}$ \\
${ }^{4}$ Ref. concentration of labile & \\
organic matter for mixing & $4.0 \mathrm{~g} / \mathrm{m}^{3}$ \\
${ }^{4}$ Mixing half saturation & \\
coefficient for oxygen & \\
\hline 1 Measured & \\
\hline
\end{tabular}

1. Measured

2. Di Toro (2001)

3. Wang (1999)

4. Di Toro and Fitzpatrick (1993).

The sorption parameters of phosphorus in sediments include sorption kinetic rate coefficients, sorption capacities, and Langmuir constants. These parameters vary substantially for different aquatic sediments and regions. The values used in this study are listed in Table 5.3. While the sorption parameters were calibrated, the sorption kinetic rates were obtained from the literature. The decomposition coefficients of organic phosphorus with different fractions were taken from the literature (Tables 5.3). 
Table 5.3. Estimated parameters of organic decomposition in sediments

\begin{tabular}{|l|c|c|}
\hline \multirow{2}{*}{\multicolumn{1}{|c|}{ Parameters }} & \multicolumn{2}{c|}{ Values } \\
\cline { 2 - 3 } & Aerobic & Anaerobic \\
\hline${ }^{1}$ Sorption rate constant $\left(\right.$ day $\left.^{-1}\right)$ & 22.8 & 1.4 \\
\hline${ }^{2}$ Labile fraction & \multicolumn{2}{|c|}{0.65} \\
\hline Refractory fraction ${ }^{2}$ & \multicolumn{2}{|c|}{0.15} \\
\hline $\begin{array}{l}{ }^{3} \text { Decomposition rate constants at } 20{ }^{\circ} \mathrm{C} \\
\left.\text { for labile fraction (day }{ }^{-1}\right)\end{array}$ & 0.0378 & 0.0253 \\
\hline $\begin{array}{l}{ }^{3} \text { Decomposition rate constants at } 20^{\circ} \mathrm{C} \\
\text { for refractory fraction }\left(\text { day }^{-1}\right)\end{array}$ & 0.0049 & 0.0037 \\
\hline
\end{tabular}

1. Olila (1992)

2. Di Toro and Fitzpatrick (1993)

3. Wang (1999)

The sediment oxygen consumption rate was determined according to the observed depth of aerobic layer at given DO concentrations (Wang, 1999):

$$
R_{o, s}=2 D_{e} \frac{(D O)_{h}}{\delta^{2}}
$$

where $\delta$ is the depth of the observed aerobic sediment layer $(m), D_{0}$ is the molecular diffusion coefficient of oxygen in sediment pore water $\left(\mathrm{m}^{2} / \mathrm{d}\right),(\mathrm{DO})_{\mathrm{h}}$ is the oxygen concentration in the overlying water $\left(\mathrm{g} / \mathrm{m}^{3}\right)$, and $\mathrm{R}_{0 . s}$ is the oxygen consumption rate in sediments in $\left(\mathrm{mg} / \mathrm{m}^{3} / \mathrm{day}\right)$. The observed depth is about $1.5 \mathrm{~cm}$ at the DO concentration of $8.28 \mathrm{mg} / \mathrm{L}$ in sediment courses incubated at the laboratory. The data result in the sediment oxygen consumption rate at $36.43 \mathrm{mg} / \mathrm{m}^{3} /$ day. 


\section{RESUlts}

\subsection{Field measurements}

\subsubsection{Water temperature dynamics}

The time series of the measured wind velocities at the lake surface and water temperatures at different depths are given in Fig. 6.1. The wind velocities display diurnal variability and range from 0 to $10 \mathrm{~m} / \mathrm{sec}$. Meteorological forcing is the major mechanism that drives the lake dynamics because the lake has no significant inflows and outflows. The thermistors at $1,3,5$, and $7 \mathrm{~m}$ were in the surface, epilimnion layer. The water temperatures respond directly to the diurnal heat and momentum input at the surface of the lake. The surface layer is considered to be an absorption layer that assimilates and redistributes the meteorological forcing in the entire lake. The thermistors at 8 and $9 \mathrm{~m}$ are in the region of strong stratification. The water temperature oscillate at different amplitudes and frequencies as the result of internal waves. Water temperatures below 10 $m$ display uniform temperatures with episodic turbulent events. In the presence of strong turbulent activities above the sediment-water interface, the water temperature was almost constant in a boundary layer of $1 \mathrm{~m}$ thickness above the lake sediments.

The time series of the water temperatures are analyzed in terms of power spectral densities (Fig. 6.2). The water temperature spectra show significant peaks in the range from 1.8 minutes to 0.43 hours. The peaks designate internal wave spectra with large variety of modes and frequencies. The peak at 0.43 hours indicates a low frequency internal seiche that is generated in Jessie Lake by wind forcing at the lake surface. 



26 22 $3.0 \mathrm{~m}$ $0_{20}^{25}$



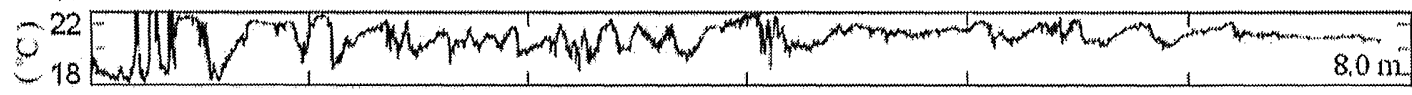

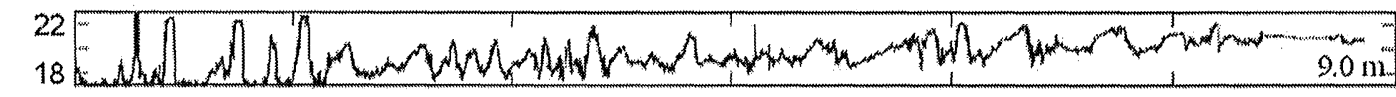


200 ${ }_{15}^{20} 5$

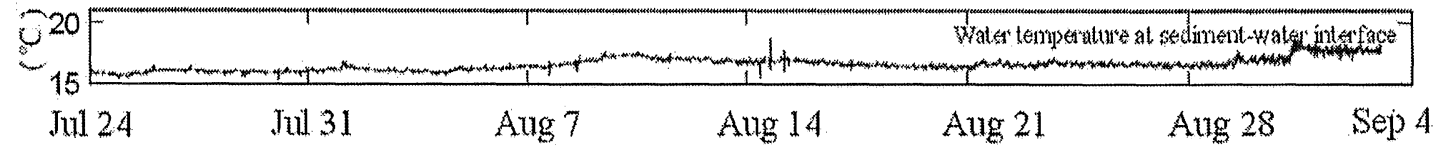

Fig. 6.1. Wind speed and water temperature data measured every 6 seconds measurements in Jessie Lake every 6 seconds from July 24 to September 4, 2001 


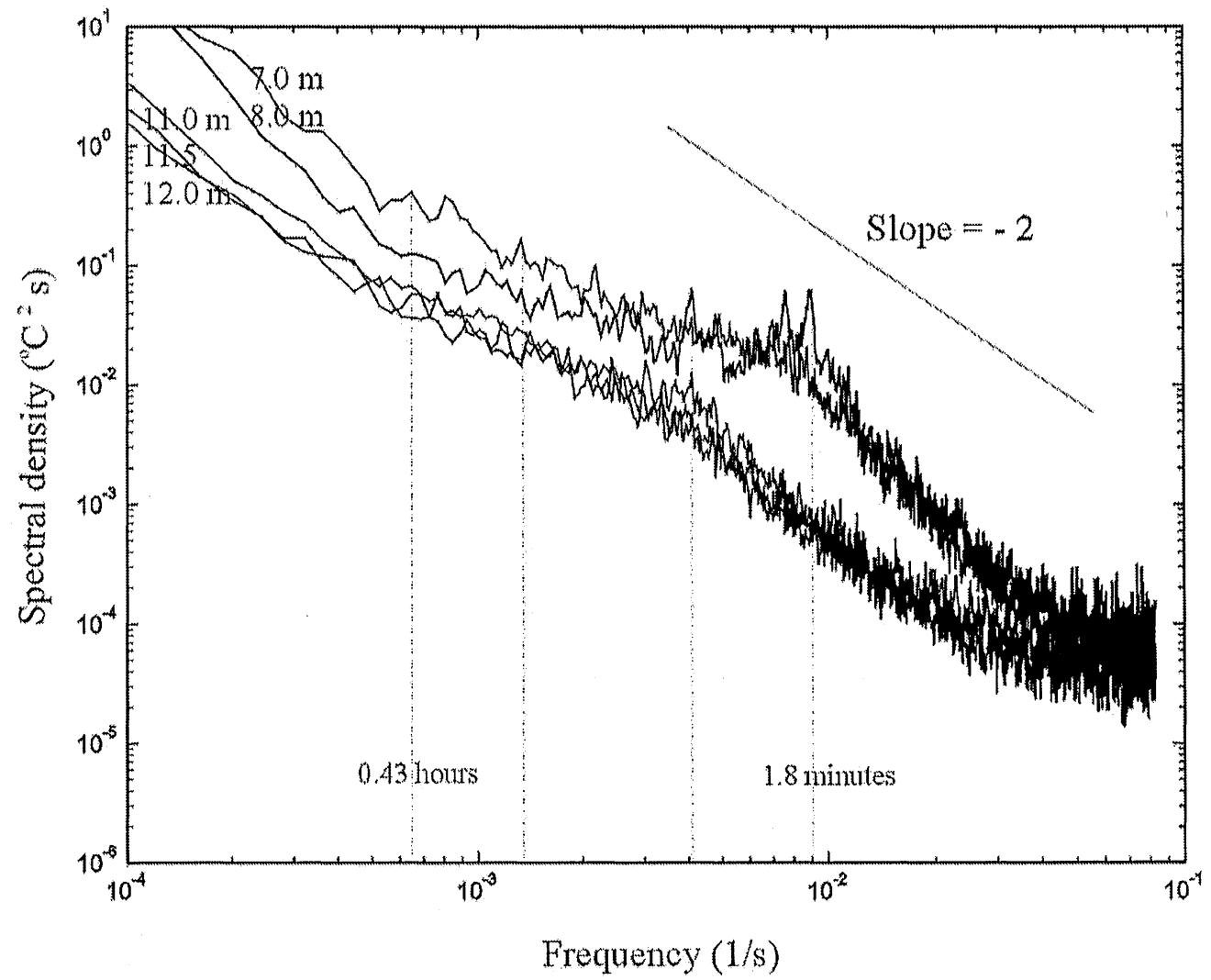

Fig. 6.2. Water temperature spectra, Jul 24 to Sep 4, 2001

\subsubsection{Water velocity}

The water velocities above the sediment-water interface are given in Fig. 6.3 and Fig. 6.4. In response to the wind forcing, the velocities ranged from $-5 \mathrm{~cm} / \mathrm{sec}$ to $5 \mathrm{~cm} / \mathrm{sec}$. Oscillatory pattern in the velocity field is generated by the internal waves in the lake. High fluctuations in the velocity field indicate intensive mixing activities at the sedimentwater interface. 

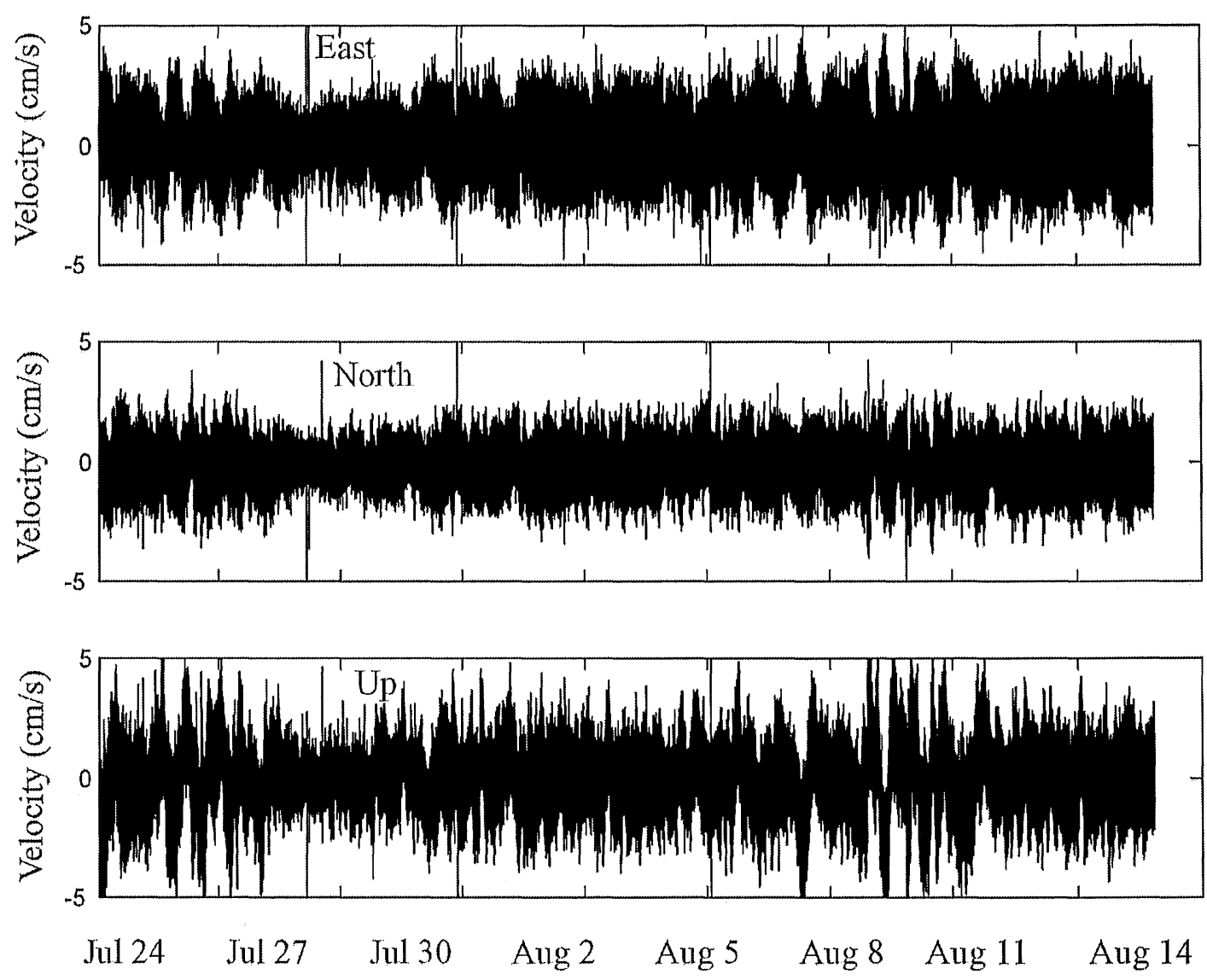

Fig. 6.3. East, North, and Upward water velocities measured every second in Jessie Lake from July 24 to August 14, 2001 

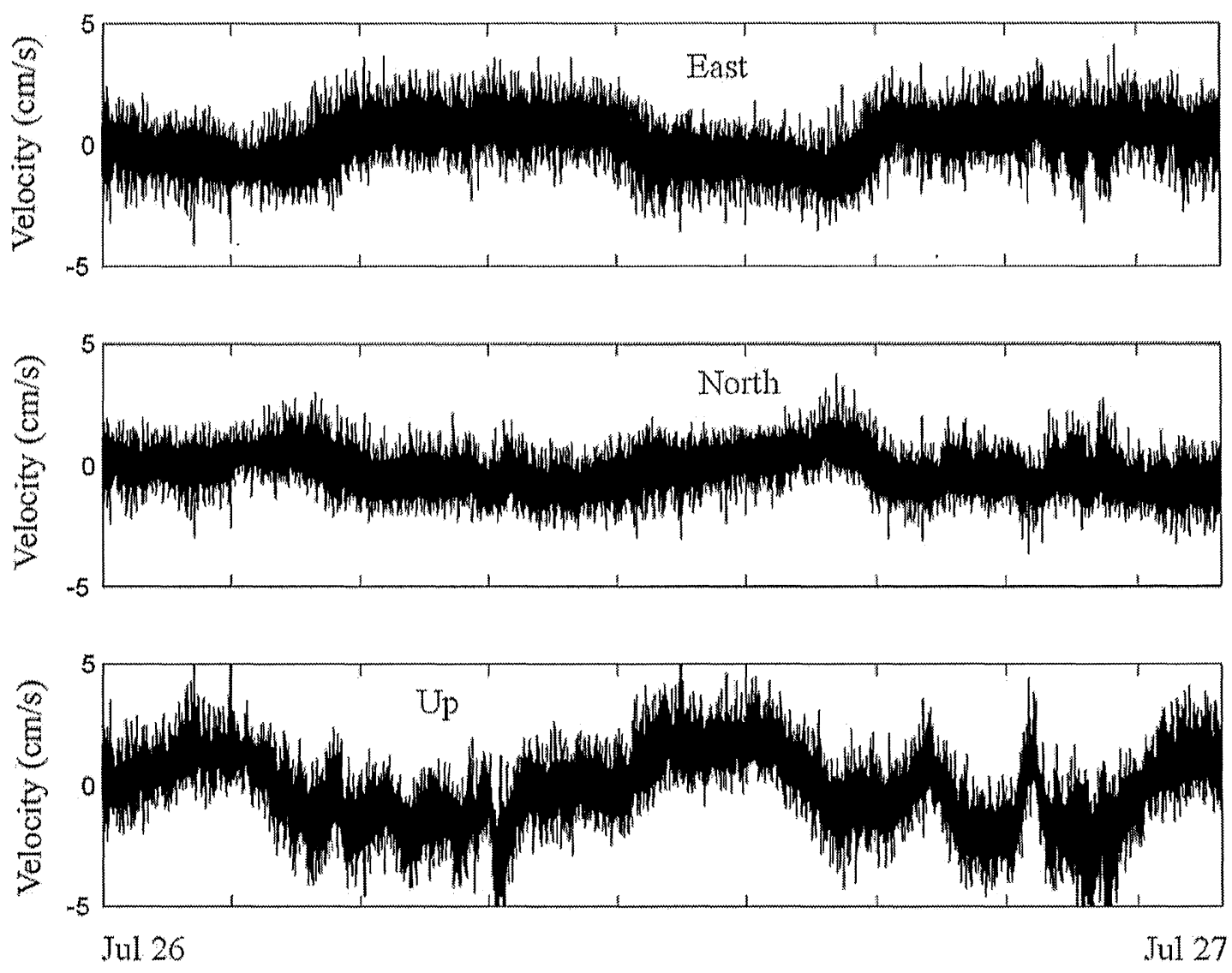

Fig. 6.4. East, North, and Upward water velocities measured every second in Jessie Lake from July 26 to July 27, 2001

\subsubsection{Microstructure measurement}

The Self-Contained Autonomous Microprofiler (SCAMP) was used to measure and record small-scale (from a meter to a tenth of a millimeter) fluid motions and properties in the lake. On deployment, the microprofiler descends at $0.1 \mathrm{~m} / \mathrm{s}$, while collecting temperature data at a rate of 100 samples per second from two pairs of sensors positioned $25 \mathrm{~mm}$ apart. The vertical temperature and microstructure measurements are given in Fig. 6.5. Fluid mixing in a mean temperature gradient produces water temperature fluctuations because exported fluid particles retain their temperature during the overturn event. Large two-sided temperature fluctuations indicate regions of vigorous mixing, and the sections with low temperature fluctuations indicate regions low activity in the water column.

The dissipation of turbulent kinetic energy, $\varepsilon$, at two characteristic depths in the water column is provided in Fig. 6.6. The high energy dissipation rate of $\varepsilon=1.3 \times 10^{-7} \mathrm{~m}^{2} / \mathrm{s}^{3}$ at the depth of $11.5 \mathrm{~m}$ is an indicator of significant mixing activities above the sedimentwater interface. 



Fig. 6.5. Water temperature with water temperature gradients measured by the SCAMP in Jessie Lake on August 16, 2001 at 12:30 p.m.
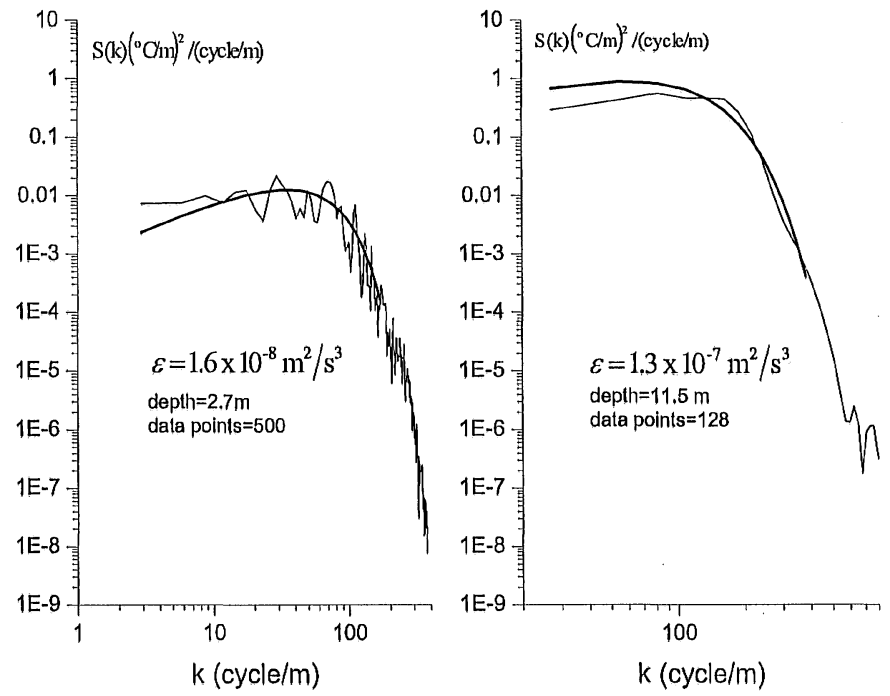

Fig. 6.6. Water temperature spectral densities with the estimate of the turbulent kinetic energy dissipation rates at $2.7 \mathrm{~m}$ and $11.5 \mathrm{~m}$ from the water surface in Jessie lake on August 16, 2001 at 12:30 p.m. 


\subsubsection{Dissolved oxygen dynamics above sediment-water interface}

Dissolved oxygen concentrations and $\mathrm{pH}$ measurements are provided in Fig. 6.7. $\mathrm{pH}$ measurements indicate a continuous increase from 7.4 to 8.2 above the sediment-water interface. Zero DO concentrations indicate anoxic conditions at the sediment-water interface during the measuring period. Periodic fluctuations in the DO concentrations were induced by intensive mixing events triggered by wind forcing above the lake surface.
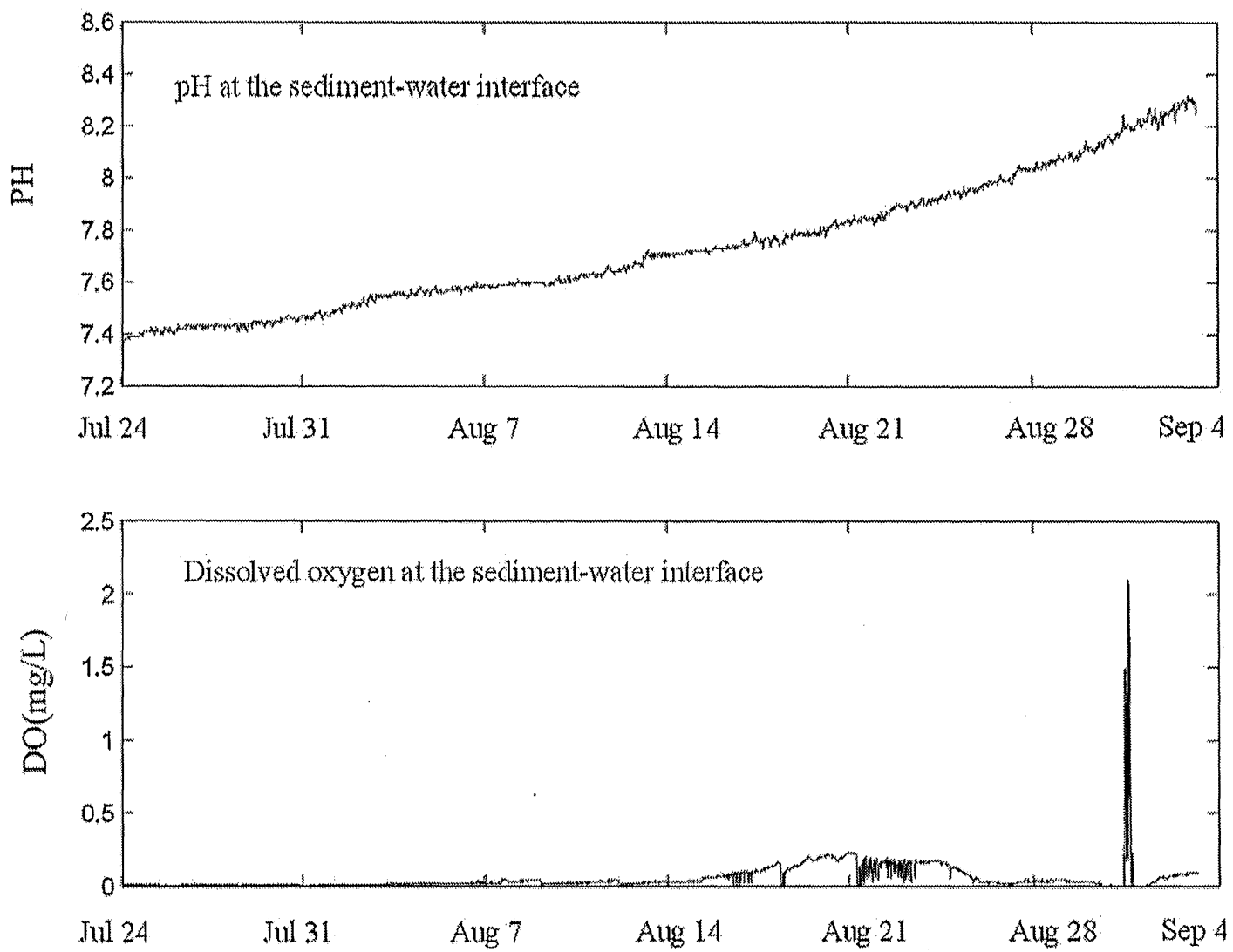

Fig. 6.7. $\mathrm{pH}$ and DO measured every 20 minutes above the sediment-water interface in Jessie Lake from Jul 24 to Sep 4, 2001.

\subsection{Laboratory measurement}

\subsubsection{Sediment water content, porosity and density}

The measured sediment water content, porosity, and density are given in Fig. 6.8, 6.9 and 6.10. These characteristics vary with the sediment depth. The water content ranged 
from 89.21 to $94.29 \%$, the porosity ranged from 88.82 to $93.74 \%$, and the sediment density ranged from 56.74 to $107.41 \mathrm{~kg} / \mathrm{m}^{3}$. The results demonstrate that the sediments in Jessie Lake have a relatively high water content, high porosity, and low sediment density.

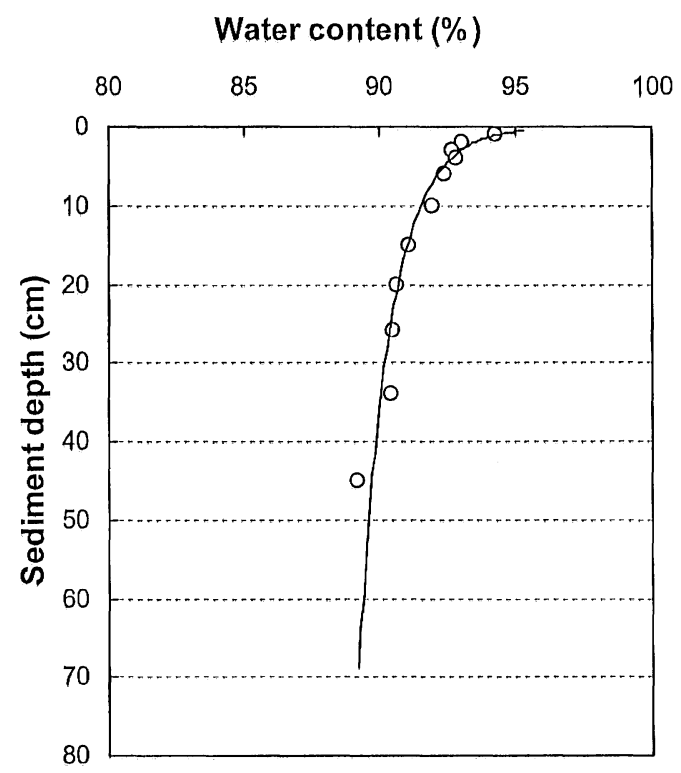

Fig. 6.8. Water content versus sediment depth in Jessie Lake

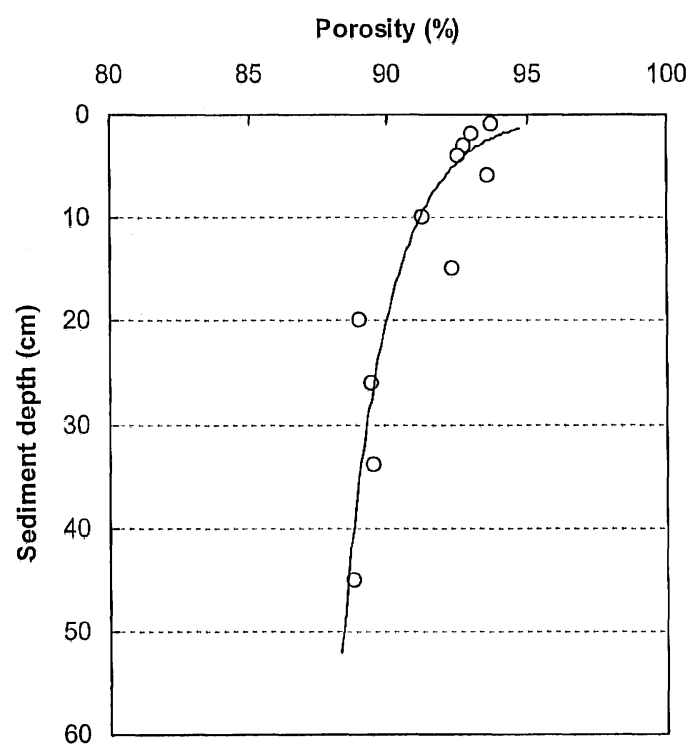

Fig. 6.9. Porosity versus sediment depth in Jessie Lake 


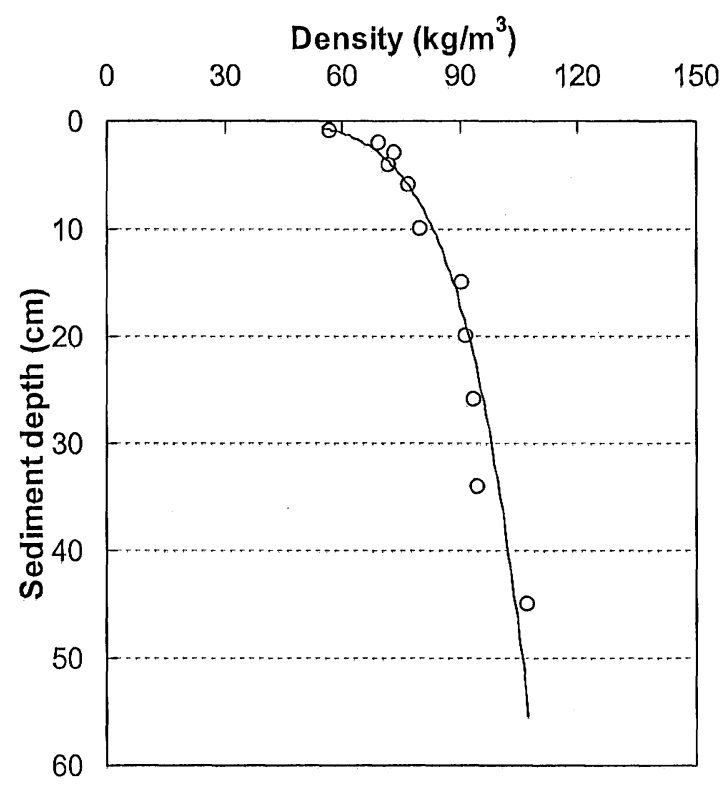

Fig. 6.10. Sediment density versus sediment depth in Jessie Lake

\subsubsection{Metal concentrations in the overlying water and sediments}

The concentration of metals in the overlying water and sediments were measured using sediment core and water samples that were collected on August 14, 2001. The concentration profiles of metals against sediment depth are shown in Fig. 6.11 and Fig. 6.12. The measurements include the metals with strong affinity to phosphorus $(\mathrm{Ca}, \mathrm{Fe}$, $\mathrm{Al}, \mathrm{Mn}, \mathrm{Mg}$ ), mineral nutrient metals (such as $\mathrm{P}, \mathrm{K}$ ), and trace metals. The mineral and trace metals are basic elements sustaining bio-growth and eutrophication. The lake has high phosphorus-affinity metal concentrations of $\mathrm{Ca}$ and $\mathrm{Mg}$ in the overlying water, followed by $\mathrm{Mn}, \mathrm{Fe}$ and $\mathrm{Al}$. In sediments, the concentrations of phosphorus-affinity metals ranged from 707.16 to $7326.0 \mathrm{mg} / \mathrm{kg}$, the mineral nutrient metals ranged from 139.19 to $574.98 \mathrm{mg} / \mathrm{kg}$, and trace metals ranged from 3.51 to $87.11 \mathrm{mg} / \mathrm{kg}$. Table 6.1 provides a comparison of phosphorus-affinity metals in Jessie Lake versus other aquatic sediments. Jesse Lake has relatively low $\mathrm{Fe}, \mathrm{Al}$, and $\mathrm{Ca}$ concentrations in the sediments, which results in a low holding capacity of phosphorus in sediments. The phosphorus, regenerated in sediments from the decomposition of organic detritus of biomass, is easily released to the overlying water. 


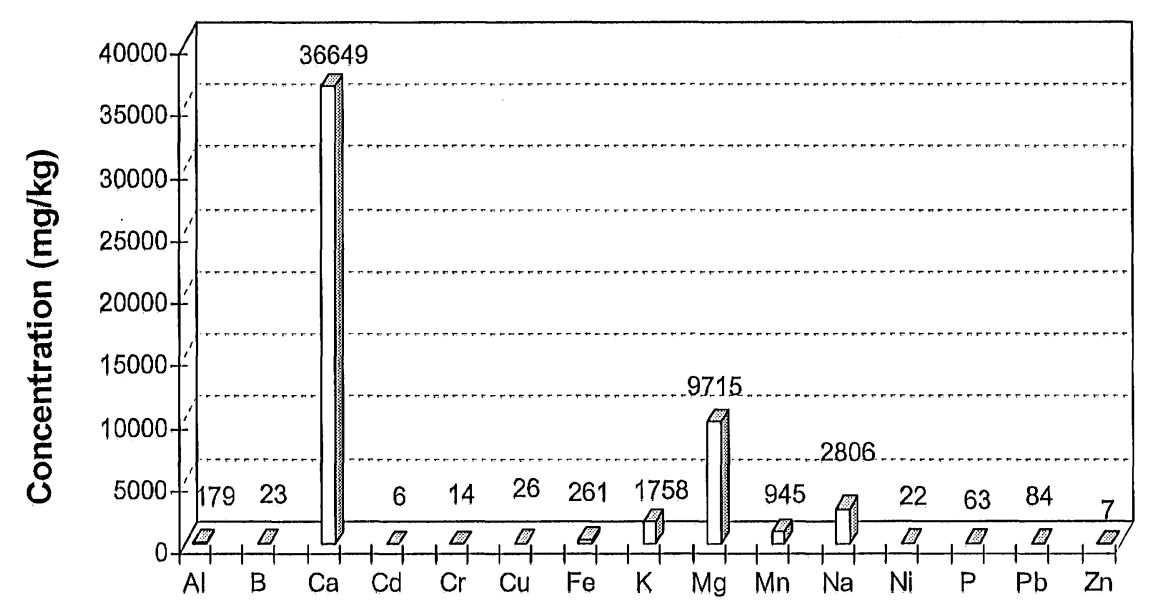

Metal in the overlying water

Fig. 6.11. Metal concentrations in the overlying water above sediment-water interface in Jessie Lake



Fig. 6.12. Metal concentrations versus sediment depth in Jessie Lake 
Table 6.1. Comparison of phosphorus-affinity metals in Jessie Lake versus other aquatic sediments $(\mathrm{g} / \mathrm{kg})^{*}$

\begin{tabular}{|l|c|c|c|c|c|l|}
\hline \multicolumn{1}{|c|}{ Watersheds } & $\mathrm{Fe}$ & $\mathrm{Al}$ & $\mathrm{Mn}$ & $\mathrm{Ca}$ & $\mathrm{Mg}$ & \multicolumn{1}{|c|}{ Reference } \\
\hline Lake Jessie, USA & 6.53 & 1.61 & 1.50 & 16.09 & 5.98 & This study \\
\hline $\begin{array}{l}\text { Okeechobee Basin, } \\
\text { USA }\end{array}$ & 1.62 & 1.11 & 2.94 & - & 0.34 & Reddy et al., (1995) \\
\hline $\begin{array}{l}\text { 14 Wisconsin } \\
\text { lakes, USA }\end{array}$ & 26.53 & 28.73 & 0.99 & - & - & $\begin{array}{l}\text { Williams et al., } \\
(1971)\end{array}$ \\
\hline $\begin{array}{l}\text { Alton Water } \\
\text { reservoir**, UK }\end{array}$ & 95.50 & - & - & 133.25 & - & $\begin{array}{l}\text { Perkins \& } \\
\text { Underwood, (2000) }\end{array}$ \\
\hline $\begin{array}{l}\text { Lake Erie, Canada } \\
\text { Kranji reservoir }\end{array}$ & 38.22 & - & 0.87 & - & - & $\begin{array}{l}\text { Williams et al., } \\
(1976)\end{array}$ \\
\hline
\end{tabular}

* The data are mean values.

** The input water in reservoir was dosed with ferric sulfate to control extern phosphorus loading.

\subsubsection{Pore-water phosphorus}

The dissolved phosphorus in the sediment of Jessie Lake was measured in July, August, and September, 2001. Results are shown in Fig. 6.13. The figure includes the overlying water phosphorus concentration at $5 \mathrm{~cm}$ above the sediment-water interface. The obtained profiles show that dissolved phosphorus concentrations decreased from the sediment surface to deep sediments. Dramatic variations are observed at the top $10 \mathrm{~cm}$. Results from different sampling dates show that the phosphorus concentrations in the top $10 \mathrm{~cm}$ remarkably increased from July to September, showing a dynamic variation of phosphorus in the sediment pore water. Maximum concentrations ranged from 414.97 to $1092.02 \mathrm{ug} / \mathrm{L}$. The observed overlying water phosphorus concentrations varied from 99.38 to $121.18 \mathrm{ug} / \mathrm{L}$. As indicated in the figure, the resultant concentration gradient of phosphorus between the sediment and overlying water varied from 293.79 to 982.77 $\mathrm{ug} / \mathrm{L}$. The gradient drives a flux of phosphorus from sediments to the water column above through pore water diffusion, bioturbation, and other transport processes. 




Fig. 6.13. Phosphorus concentration profiles in sediments

\subsubsection{Phosphorus fractionation}

The understanding of different species of phosphorus existing in sediments is important as it can provide information of phosphorus dynamics in sediments. Phosphorus species associated with its function in sediments are summarized in Fig. 6.14. Dissolved phosphorus and particulate phosphorus were studied in the sediments of Jessie Lake. Dissolved ortho-phosphorus is biologically available and sustains eutrophication processes as discussed in Section 6.2.3. Particulate phosphorus of organic and inorganic phosphorus acts as a source for dissolved reactive phosphorus. Organic phosphorus produces dissolved phosphorus through bio-decomposition while inorganic phosphorus releases dissolved reactive phosphorus through sorption processes. Inorganic particulate phosphorus can be further divided into loosely bound phosphorus, $\mathrm{Fe}$ and $\mathrm{Al}$ bound phosphorus, and $\mathrm{Ca}$ bound phosphorus, which have different mobilization abilities.

The concentration profile of total phosphorus in Jessie Lake sediments is plotted in Fig. 6.15. The concentrations ranged from 1179.1 to 2455.5 to ug/g Dry Weight. Three phosphorus species by chemical extraction are demonstrated in Fug. 6.16. A loosely bound phosphorus ranged from 0.75 to $22.21 \mathrm{ug} / \mathrm{g}$ DW. This fraction of phosphorus usually represents the labile form of readily releasable phosphorus. Fe and Al bound phosphorus ranged from 6.92 to 76.98 to $\mathrm{ug} / \mathrm{g} \mathrm{DW}$. This fraction is exchangeable between the particulate and dissolved phases through sorption processes. $\mathrm{Ca}$ bound phosphorus ranged from 41.94 to $70.77 \mathrm{ug} / \mathrm{g} \mathrm{DW}$. Ca bound phosphorus refers to the fraction that is fixed in sediments and may be lost into deep sediments through burial process. Remarkable spatial variability of these phosphors fractions are evident in the top $10 \mathrm{~cm}$ of lake sediments. 




Fig. 6.14. Summary of phosphorus species in Jessie Lake sediments

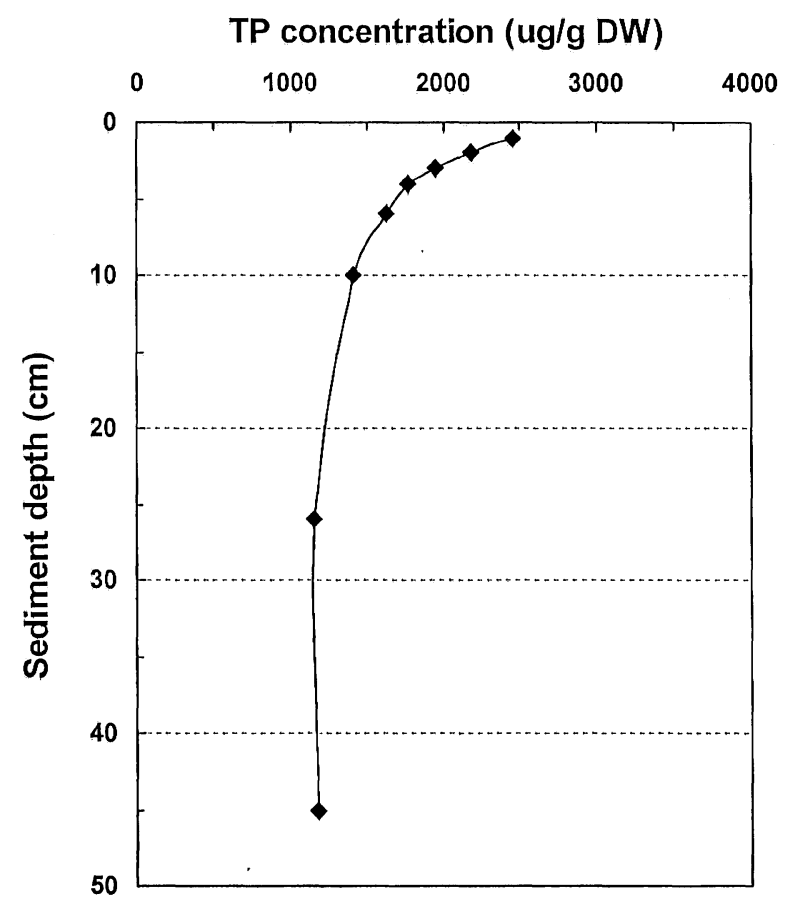

Fig. 6.15. Total phosphorus concentrations in Jessie Lake sediments 


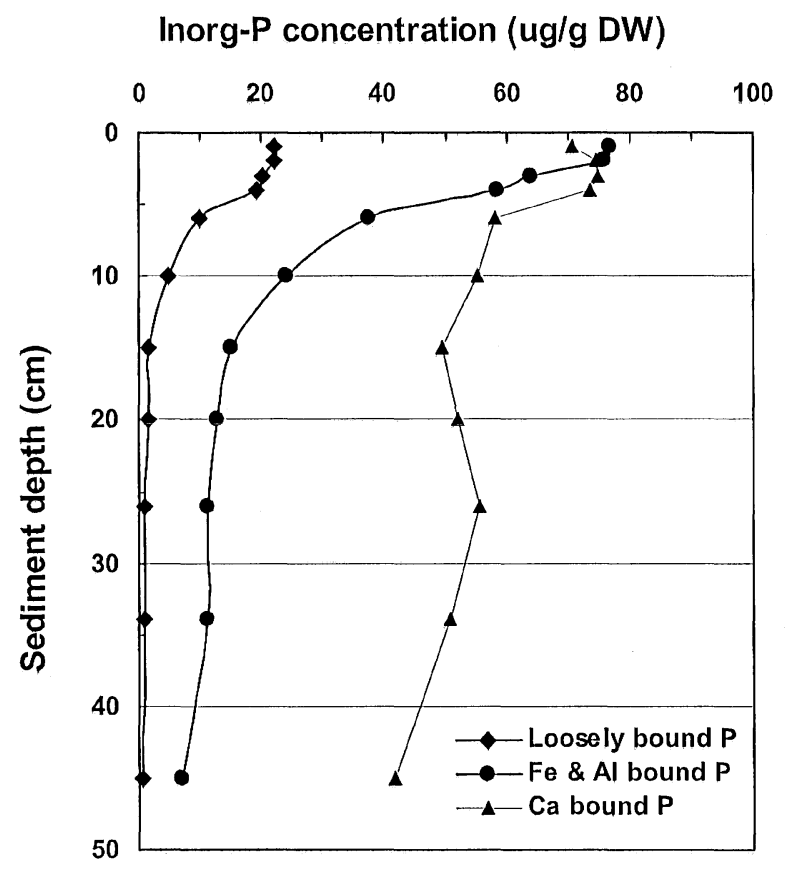

Fig. 6.16. Inorganic phosphorus concentrations by chemical extraction scheme in Jessie Lake sediments

Phosphorus fractions measured in the lake sediments at the top $10 \mathrm{~cm}$ are shown in Fig. 6.17. The residual phosphorus fraction was estimated as the difference between the total phosphorus and chemically extracted phosphorus, mostly consisting of organic phosphorus (Ting and Appan, 1996). The loosely bound labile phosphorus fraction accounts for only $0.8 \%$ of total phosphorus in Jessie Lake, metal bound exchangeable phosphorus accounts for $2.9 \%$, and $\mathrm{Ca}$ bound phosphorus accounts for $3.6 \%$. The remaining $92.7 \%$ is highly resistant insoluble phosphorus. The mobile inorganic phosphorus accounts for a very small portion in Jessie Lake and most of the phosphorus is organic and resistant insoluble phosphorus. This organic phosphorus may generate labile inorganic phosphorus during the bio-decomposition processes (Wang, 1999). Due to the low holding capacity of phosphorus and high storage of potential phosphorus sources in the sediments, Jessie Lake has a high potential for internal loading of phosphorus. 


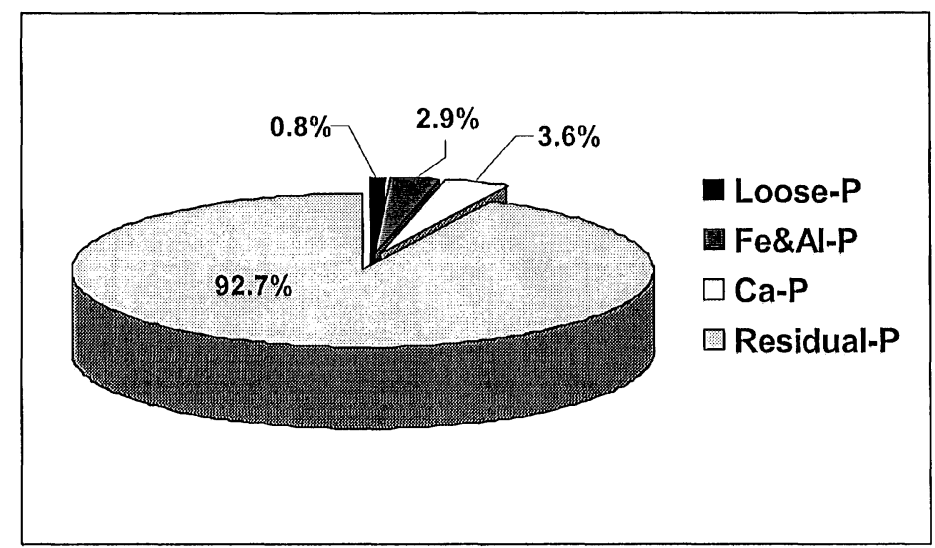

Fig. 6.17. Phosphorus species in Jessie Lake sediments

Compared to other reported lake sediments (Table 6.2), Jessie Lake has an average total concentration of phosphorus in the sediments. However, the sediments have very high organic and resistant insoluble phosphorus content. The primary reason is probably due to the low phosphorus-affinity metal concentrations such Fe and A1. The phosphorus regenerated in sediments from the decomposition of organic detritus of biomass is continuous source of internal loading in the lake. Sediment conditioning techniques such as chemical dosing of iron and aluminum salts can be a potential measure used to control the internal loading of phosphorus from the sediments.

Table 6.2. Comparison of phosphorus composition between Jessie and other lakes (L-P is the labile phosphorus, Fe-P is the Fe \& $\mathrm{Al}$ bound phosphorus, $\mathrm{Ca}-\mathrm{P}$ is the $\mathrm{Ca}$ bound phosphorus and Res-P is the residual phosphorus)

\begin{tabular}{|c|c|c|c|c|c|c|}
\hline \multirow[t]{2}{*}{ Lake } & \multirow{2}{*}{$\begin{array}{l}\text { Total P } \\
(\mathrm{mg} / \mathrm{kg})\end{array}$} & \multicolumn{4}{|c|}{ Chemical extraction fraction (\%) } & \multirow[t]{2}{*}{ Reference } \\
\hline & & L-P & Fe-P & Ca- P & Res-P & \\
\hline $\begin{array}{l}\text { Lake Jessie, } \\
\text { USA }\end{array}$ & 1579 & 0.8 & 2.9 & 3.6 & 92.7 & This study \\
\hline $\begin{array}{l}\text { Okeechobee } \\
\text { Basin, USA }\end{array}$ & $72-1079$ & $0.1-2.3$ & $\begin{array}{c}20.0- \\
70.1\end{array}$ & $\begin{array}{l}13.0- \\
50.0\end{array}$ & $43-51$ & Reddy et al., (1995) \\
\hline $\begin{array}{l}14 \text { Wisconsin } \\
\text { lakes, USA }\end{array}$ & $\begin{array}{l}580- \\
7000\end{array}$ & - & - & - & $\begin{array}{l}20.3- \\
37.0^{*}\end{array}$ & $\begin{array}{l}\text { Williams et al., } \\
\text { (1971) }\end{array}$ \\
\hline $\begin{array}{l}\text { Lake Erie, } \\
\text { Canada }\end{array}$ & $\begin{array}{l}188- \\
2863\end{array}$ & - & - & - & $\begin{array}{c}0.8- \\
26.4^{*}\end{array}$ & $\begin{array}{l}\text { Williams et al., } \\
\text { (1976) }\end{array}$ \\
\hline $\begin{array}{l}\text { Kranji reservoir, } \\
\text { Singapore }\end{array}$ & $\begin{array}{l}1885- \\
1640\end{array}$ & $0.4-0.5$ & $\begin{array}{l}53.0- \\
63.0\end{array}$ & $6.6-8.5$ & $\begin{array}{l}28.2- \\
39.2\end{array}$ & $\begin{array}{l}\text { Ting \& Appan } \\
\text { (1996) }\end{array}$ \\
\hline
\end{tabular}

* Total organic fraction. 


\subsection{Phosphorus flux simulation}

\subsubsection{General characteristics of phosphorus release processes}

A laboratory setup with sediment cores is given in Fig. 6.18. The experiments were conducted over two weeks. In order to investigate the effect of DO on the phosphorus release, experiments were conducted under the aerobic and anaerobic conditions. During the experiments, concentrations of dissolved reactive phosphorus (DRP) and DO in the water were monitored (Fig. 6.19).


Fig. 6.18. Experimental setup with sediment cores at the laboratory

Under the aerobic condition, DRP in the water columns decreased from 37.17 to $19.30 \mu \mathrm{g} / \mathrm{L}$ and then kept relatively constant when DO was maintained in the range from 8.08 to $8.31 \mathrm{mg} / \mathrm{L}$. After switching aeration gases (from oxygen to nitrogen), the DO in the aerobic chamber decreased from 8.24 to $0.38 \mathrm{mg} / \mathrm{L}$. The corresponding DRP increased from 19.73 to $127.50 \mu \mathrm{g} / \mathrm{L}$ during 4 days. Under the anaerobic condition, however, DRP increased linearly during first 9 days from 52.33 to $632.07 \mu \mathrm{g} / \mathrm{L}$ when DO was kept at 0.69 to $0.26 \mathrm{mg} / \mathrm{L}$ and then appeared to increase slowly or keep constant. After switching aeration gases, DRP dropped from 619.69 to $165.81 \mu \mathrm{g} / \mathrm{L}$ when DO increased from 0.28 to $8.35 \mathrm{mg} / \mathrm{L}$. The results indicate that DRP and its release flux from 
sediments are sensitive to DO. Under the anaerobic conditions, DRP release from sediments was significant. Under the anaerobic conditions, DRP in the water column settles to sediments. DRP flux was not observed under the aerobic condition.


Fig. 6.19 Release processes of DRP from sediment cores to water column in laboratory simulation. The sediment cores were collected from Jessie Lake on September $5,2001$.

\subsubsection{Determinations of phosphorus release flux}

The release flux of phosphorus were estimated according to the DRP concentration variations with time as:

$$
F_{r e l}=\frac{V_{w^{\prime}}}{A_{s}} \frac{d(D P)_{w}(t)}{d t}
$$


where $F_{\text {rel }}$ is the phosphorus release flux $\left(\mathrm{mg} / \mathrm{m}^{2} / \mathrm{day}\right), V_{\mathrm{w}}$ is the total volume of the overlying water in reaction chamber $\left(\mathrm{m}^{3}\right), \mathrm{A}_{\mathrm{s}}$ is the area of the sediment-water interface of sediment cores $\left(\mathrm{m}^{2}\right)$, and (DP) $)_{\mathrm{w}}(\mathrm{t})$ is the accumulated DRP concentrations at the time $t$ in the overlying water $\left(\mathrm{mg} / \mathrm{m}^{3}\right)$. Equation (2) can be written as

$$
F_{r e l}=\frac{V_{w}}{A_{s}} \frac{\Delta(D P)_{w}}{\Delta t}
$$

where $\Delta(D P)_{\mathrm{w}}$ is the concentration difference within a linear change, $\Delta t$ is the time span. The estimated flux of DRP from the sediment to the overlying water was 16.93 $\mathrm{mg} / \mathrm{m}^{2} /$ day under the anaerobic condition. The flux of DRP was not observed under the aerobic conditions.

\subsection{Numerical modeling}

\subsubsection{Model calibration}

The model input includes the state parameters as discussed in Section 5.2 and field measurements of overlying water temperature, $\mathrm{DO}$, dissolved phosphorus concentrations above the sediment-water interface, and organic depositional fluxes. The organic depositional flux and adsorption non-linear partitioning parameters were not available. The parameters were estimated by calibration. The calibration was based on the organic phosphorus content, dissolved and exchangeable phosphorus concentrations measured in the top $5 \mathrm{~cm}$ sediments as discussed in Section 6.2.3 and 6.2.4. The calibrated values of organic depositional flux and non-linear sorption partitioning parameters are provided in Table 6.3.

Table 6.3. Model parameters

\begin{tabular}{|l|c|c|}
\hline \multicolumn{1}{|c|}{ Parameters } & $\begin{array}{c}\text { Calibrated } \\
\text { using our model }\end{array}$ & Estimated/literature values \\
\hline $\begin{array}{l}\text { Organic deposition flux } \\
\left(\mathrm{mg} \mathrm{P} / \mathrm{m}^{2} / \mathrm{d}\right)\end{array}$ & 12.4 & $6.3-15,6^{*}$ \\
\hline $\begin{array}{l}\text { Sorption isotherm constant } \\
(\mathrm{L} / \mathrm{mg})\end{array}$ & 7.5 & $13^{* *}$ \\
\cline { 2 - 3 } & 2.4 & $2.6^{* *}$ \\
\hline Sorption capacity & 0.90 & $0.7^{* *}$ \\
\hline (mg/g) & 0.13 & $0.4^{* *}$ \\
\hline
\end{tabular}

* Estimated using field measurements of chlorophyll $a$ concentration.

** Furumai and Ohgaki (1989). 


\subsubsection{Short-term simulation}

The simulated reactive organic phosphorus concentrations from August 14 to September 6, 2001 are provided in Fig. 6.20. The concentrations of three phosphorus forms were relatively constant during the three-week simulation period. The simulated reactive organic phosphorus concentrations were low compared with the total phosphorus, indicating that the main proportion of the organic phosphorus in sediments is the non-degradable component. The results agree well with the measurements as shown in Table 6.4, in which reactive organic phosphorus is the sum of decomposable labile and refractory fractions. The estimates of reactive organic phosphorus were based on the measured total organic phosphorus (Section 6.2.4), labile organic fraction of $3.26 \%$, and refractory fraction of $9.21 \%$ (Wang 1999).

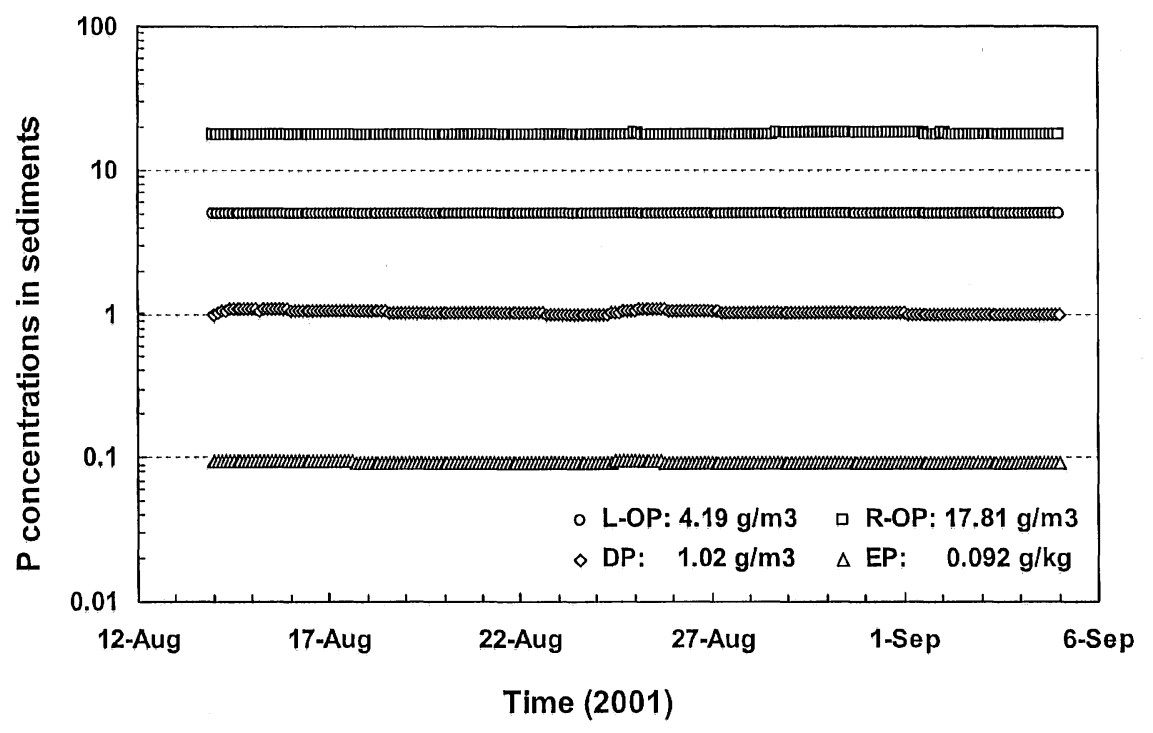

Fig. 6.20 Simulated reactive organic phosphorus concentrations of labile and refractory decomposition fraction (L-OP and R-OP), pore water and exchangeable particulate phosphorus concentrations (DP and EP).

The release flux of phosphorus across the sediment-water interface is a primary concern in modeling the water-sediment interaction. Simulated phosphorus flux with measured DO concentrations are plotted in Fig. 6.21. During the three-week simulation period, the phosphorus flux ranged from 3.02 to $15.6 \mathrm{mg} / \mathrm{m}^{2} / \mathrm{d}$. On August 25, 2001, the low flux corresponds to relatively high DO concentrations $(1.09 \mathrm{mg} / \mathrm{L})$ at the sedimentwater interface, caused by a windstorm. Increased DO concentration changed the redox potential of sediments from anaerobic to aerobic conditions. The magnitude of simulated phosphorus flux is close to $16.93 \mathrm{mg} / \mathrm{m}^{2} /$ day that was obtained through experimental measurements under laboratory conditions. 
Table 6.4. Comparison of the model calibrations versus field measurements

\begin{tabular}{|l|c|c|}
\hline \multicolumn{1}{|c|}{ Parameters } & $\begin{array}{c}\text { Calibrated using } \\
\text { our model (Mean) }\end{array}$ & $\begin{array}{c}\text { Estimated using our } \\
\text { measurements }\end{array}$ \\
\hline Reactive organic phosphorus $\left(\mathrm{g} / \mathrm{m}^{3}\right)$ & 23.0 & $14.4-20.8$ \\
\hline Dissolved phosphorus $\left(\mathrm{g} / \mathrm{m}^{3}\right)$ & 1.0 & $0.4-1.1$ \\
\hline Exchangeable particulate phosphorus $(\mathrm{g} / \mathrm{kg})$ & 0.092 & $0.078-0.099$ \\
\hline
\end{tabular}
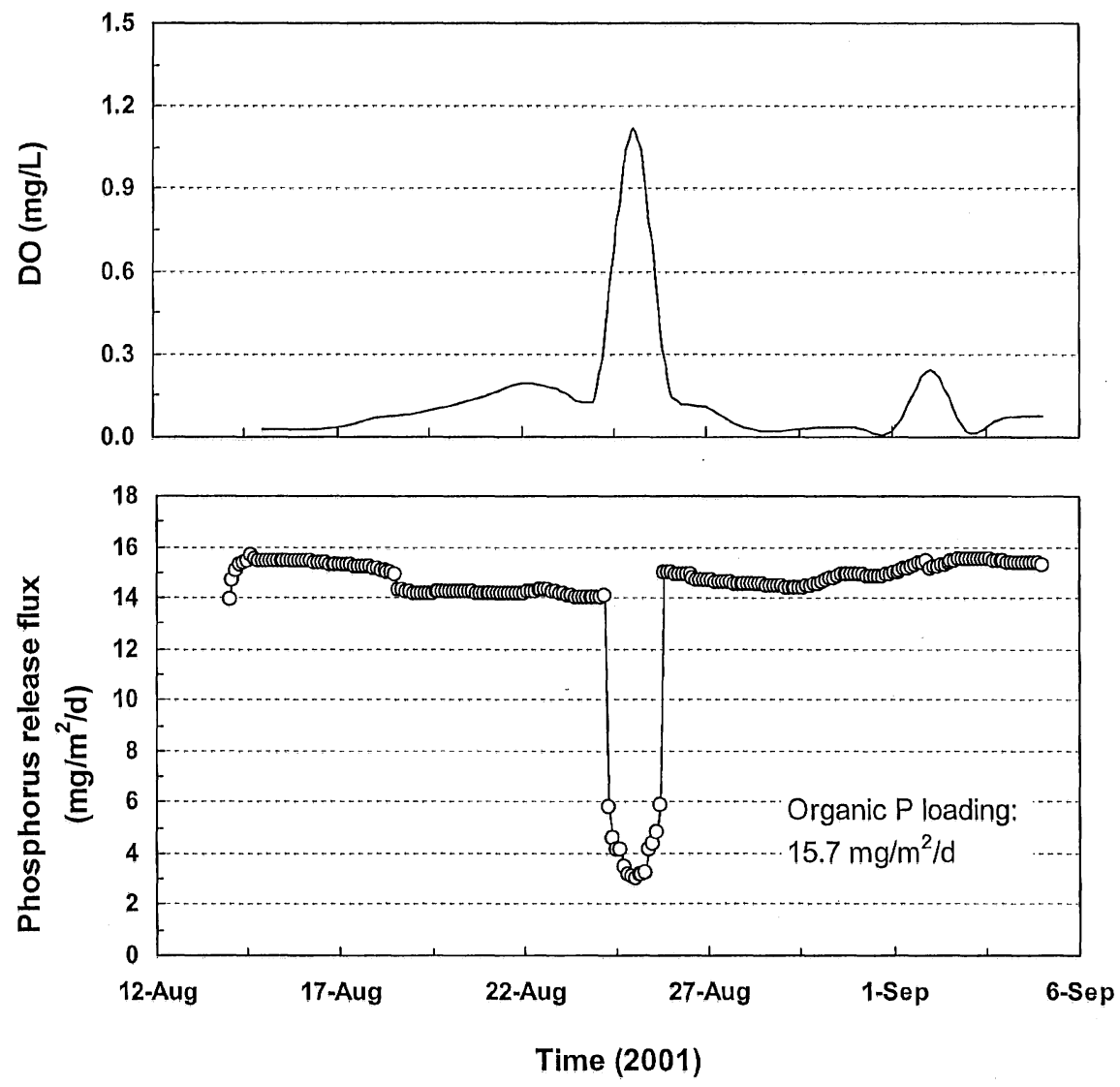

Fig. 6.21. Simulated release flux of phosphorus and measured DO concentrations from August 14 to September 6, 2001, Jessie Lake

As shown in Table 6.4, the estimated organic loading from the overlying water to sediments ranged from 6.3 to $15.6 \mathrm{mg} \mathrm{P} / \mathrm{m}^{2} / \mathrm{d}$. The dependence of phosphorus release flux on organic loading is provided in Fig, 6.22 and 6.23. The simulated flux ranged from 1.6 to $28.1 \mathrm{mg} / \mathrm{m}^{2} / \mathrm{d}$ when organic phosphorus loading ranged from 1.5 to 30 $\mathrm{mg} / \mathrm{m}^{2} / \mathrm{d}$. As demonstrated in the figure, when organic loading is as low as $1.5 \mathrm{mg} \mathrm{P}$ $/ \mathrm{m}^{2} / \mathrm{d}$, phosphorus flux is negative, i.e. sediments act as a sink rather than a source for phosphorus, when the DO above sediment-water interface is larger than $1.09 \mathrm{mg} / \mathrm{L}$. 


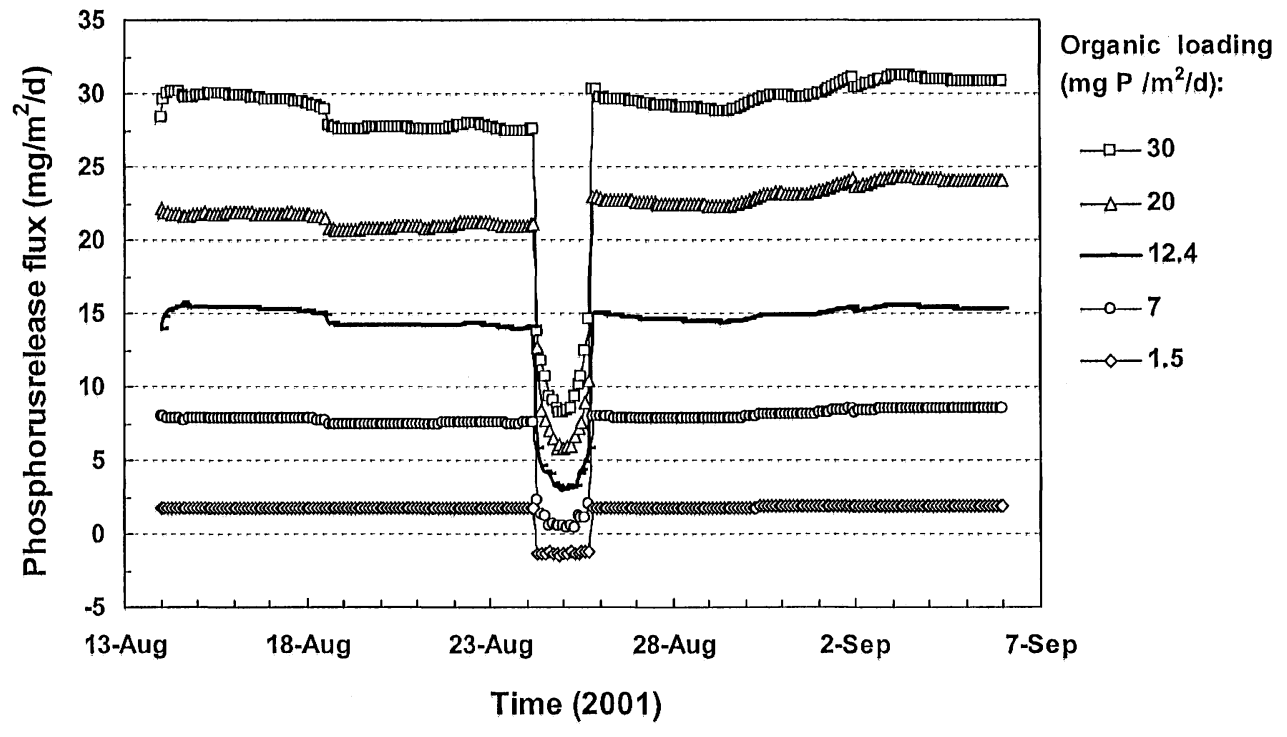

Fig. 6.22. Release fluxes simulated under different organic loadings.

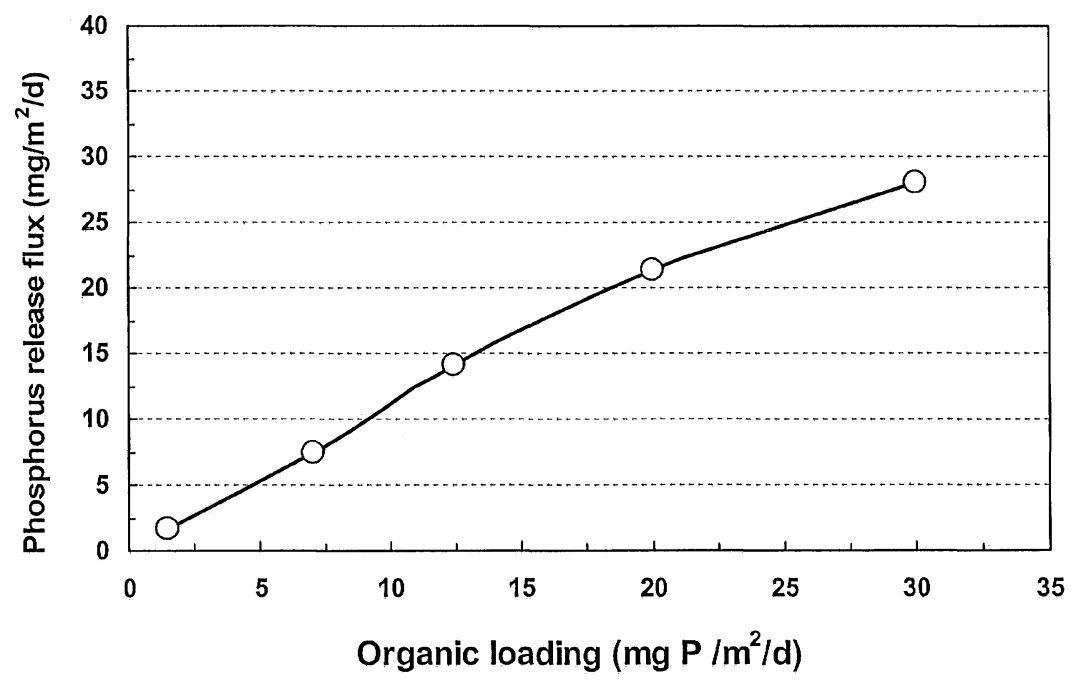

Fig. 6.23. Relationship between phosphorus release flux and organic loading.

\subsubsection{Long-term prediction}

For the long-term prediction of phosphorus flux, organic depositional loading is required. The depositional flux is assumed to be directly proportional to the overlying water biomass concentration (Smits and der van Mollen, 1993). Organic depositional loading can be approximated as: 


$$
F(t)=F_{0} f(t)
$$

where $F_{0}$ is the current organic loading $\left(\mathrm{mg} / \mathrm{m}^{2} / \mathrm{d}\right)$, and $\mathrm{f}(\mathrm{t})$ is the empirical time function. In Jessie Lake, the field measurements of chlorophyll $a$ were available from 1998 to 2000. Based on the limited data, the following empirical equation of organic loading is proposed

$$
f(t)=12.4[0.3712 \ln (t)+1.1567)]
$$

where $t$ is time (year). Fig. 6.24 shows the predictions of internal loading of phosphorus released from sediments to the overlying water in Jessie Lake for the next 30 years. The predictions include the internal loadings based on current condition (Equation 5) and five hypothetical scenarios. The five scenarios assume the following conditions: a) organic loading remains unchanged, b) organic loading decreases annually by $1 \%, \mathrm{c}$ ) organic loading decreases annually by $5 \%$, d) organic loading decreases annually by $10 \%$, and e) organic loading decreases annually by $25 \%$. The scenarios b) to e) reflect possible restoration measures in the Jessie Lake. Without any restoration initiative, the internal phosphorus loading will increase from 14.1 to $31.9 \mathrm{mg} / \mathrm{m}^{2} / \mathrm{d}$ in the next 30 years. The larger the reduction of organic loading the faster the reduction in internal loading is evident. For example, the $25 \%$ reduction in organic loading will reduce the phosphorus release flux almost to zero in the next 10 years.

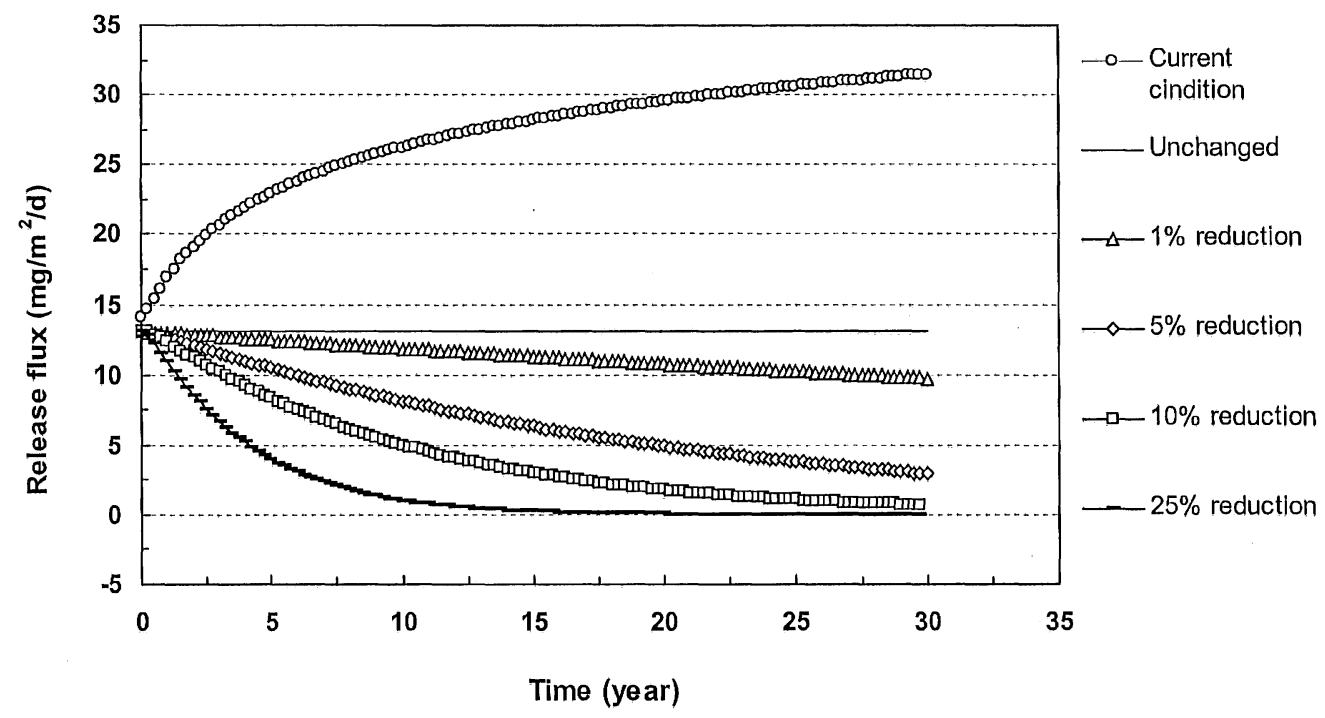

Fig. 6.24. Long-term predictions of internal loading of phosphorus released from sediments to the overlying in Jessie Lake for the next 30 years. 


\section{CONCLUSIONS AND RECOMMENDATIONS}

\subsection{Conclusions}

Based on our filed and laboratory measurements, our findings are summarized below.

\section{Field measurements}

- The water temperatures at the sediment-water interface ranged from $15^{\circ} \mathrm{C}$ to $18^{\circ} \mathrm{C}$ during the measurement period from July 24 to September 4, 2001. The temperature oscillations in the water column were driven by the internal wave activities that were triggered by wind-forcing above the lake surface.

- The water velocities above the sediment-water interface revealed an oscillatory flow with velocity fluctuations $\pm 5 \mathrm{~cm} / \mathrm{sec}$ from July 24 to August 14, 2001. Velocity fluctuations with high energy dissipation rates are indicators of a turbulent flow at the sediment-water interface in the lake.

- The concentration of DO was close to zero from July 24 to September 4, 2001. The anoxic conditions were disrupted by periodic mixing events that were induced by wind-forcing above the lake surface. During the measurement period, $\mathrm{pH}$ changed from 7.2 to 8.4 .

\section{Laboratory studies}

- The sediments in Jessie Lake have relatively high water content, high porosity, and low density. The water content ranged from 89.21 to $94.29 \%$, while the porosity ranged from 88.82 to $93.74 \%$, and the density ranged 56.74 to 107.41 $\mathrm{kg} / \mathrm{m}^{3}$. The water content and porosity decreased with the depth.

- A chemical analysis demonstrated that the concentration of phosphorus-affinity metals ranged from 707.16 to $7326.0 \mathrm{mg} / \mathrm{kg}$, while the mineral nutrients ranged from 139.19 to $574.98 \mathrm{mg} / \mathrm{kg}$, and the trace metals ranged from 3.51 to 87.11 $\mathrm{mg} / \mathrm{kg}$. In comparison to other lakes and reservoirs, Jessie Lake has relatively low phosphorus-affinity metal concentrations in the sediments, as represented by iron, aluminum, and calcium. The low phosphorus-affinity metal concentration can result in a low holding capacity of phosphorus in sediments. The phosphorus regenerated in the sediments from the decomposition of the organic detritus of biomass, was rapidly released to the overlying water, sustaining the high phosphorus concentration in the water column. 
- The dissolved phosphorus concentrations in the sediments decreased from the sediment-water interface to the deep sediments. Dramatic variations are observed in the top $10 \mathrm{~cm}$, showing a dynamic feature. The concentration of phosphorus in the top $10 \mathrm{~cm}$ of sediments varied spatially and temporally. The maximum concentration varied from 414.97 to $1092.02 \mathrm{ug} / \mathrm{L}$ from July to September 2001. The difference in concentration between the phosphorus in the overlying water and lake sediments ranged from 293.79 to $982.77 \mathrm{ug} / \mathrm{L}$.

- The total phosphorus concentration ranged from 2455.5 to $1179.1 \mathrm{ug} / \mathrm{g}$ DW from the sediment-water interface to the $45 \mathrm{~cm}$ deep sediments. The loosely bound phosphorus ranged from 22.21 to $0.75 \mathrm{ug} / \mathrm{g} \mathrm{DW}$, while the exchangeable phosphorus bound by $\mathrm{Fe}$ and $\mathrm{Al}$ ranged from 76.98 to $6.92 \mathrm{ug} / \mathrm{g} \mathrm{DW}$, and the $\mathrm{Ca}$ bound phosphorus ranged from 70.77 to $41.94 \mathrm{ug} / \mathrm{g} \mathrm{DW}$. A loosely bound labile phosphorus fraction accounts for only $0.8 \%$ of the total phosphorus in Jessie Lake, while the metal bound exchangeable phosphorus accounts for $2.9 \%$, and the $\mathrm{Ca}$ bound phosphorus accounts for $3.6 \%$. The remaining $92.7 \%$ is organic phosphorus and highly resistant insoluble inorganic phosphorus.

The mobile inorganic phosphorus accounts for a very small portion of the Jessie Lake sediments. Most of the phosphorus is organic and resistant, insoluble phosphorus. The organic phosphorus has a high potential to generate labile inorganic phosphorus through the bio-decomposition processes. Compared to the data reported in other lakes, Jessie Lake has an average level of total phosphorus concentrations in the sediments, but the sediments contain extremely high organic and resistant, insoluble phosphorus concentrations. Due to the low holding capacity of the sediments and high potential for phosphorus regeneration, Jessie Lake has a high potential for the internal loading of phosphorus.

- Dissolved reactive phosphorus in the overlying water and its release flux from the sediments were sensitive to the DO concentration in the water column. A substantial amount of dissolved reactive phosphorus was released from the sediments under the anaerobic conditions, while the phosphorus in the water column settled onto the sediments under aerobic conditions. The measured release flux of phosphorus from the sediments to the overlying water was 16.93 $\mathrm{mg} / \mathrm{m}^{2} /$ day under the anaerobic conditions. The release flux was not observed under the aerobic conditions.

\section{Numerical modeling}

- The simulated concentrations of reactive organic phosphorus, dissolved phosphorus, and exchangeable phosphorus were relatively constant during the study period from August 14 to September 6, 2001. The average values over the simulation period were: $23 \mathrm{~g} / \mathrm{m}^{3}$ (organic phosphorus), $1.0 \mathrm{~g} / \mathrm{m}^{3}$ (dissolved phosphorus), and $0.092 \mathrm{~g} / \mathrm{kg}$ (exchangeable phosphorus). The release flux of phosphorus from the lake sediments to the overlying water ranged from 3.02 to $15.6 \mathrm{mg} / \mathrm{m}^{2} /$ day. The simulated flux was sensitive to the DO concentration above 
the sediment-water interface. The higher the DO concentration became, the lower the release flux was.

- The long-term simulation results indicate that if organic loading to the lake sediments continues at the rate observed in the past, the internal loading of phosphorus from sediments to the overlying water would be doubled from the current $14.1 \mathrm{mg} / \mathrm{m}^{2} / \mathrm{d}$ to $31.9 \mathrm{mg} / \mathrm{m}^{2} / \mathrm{d}$ after 30 years. However, if the organic loading is reduced with an implementation of restoration measures, the internal loading would decline gradually. The reduction in the organic loading of $1 \%, 5 \%$, $10 \%$ and $25 \%$ corresponds to the internal phosphorus reduction from the current loading of $14.1 \mathrm{mg} / \mathrm{m}^{2} / \mathrm{d}$ to $9.7,3.0,0.7$, and $0 \mathrm{mg} / \mathrm{m}^{2} / \mathrm{d}$, respectively.

\subsection{Recommendation for restoration and further studies}

Based on the study results, Jessie Lake has an average phosphorus release flux of 15.6 $\mathrm{mg} / \mathrm{m}^{2} /$ day under anaerobic conditions, a high potential source of internal phosphorus loading, a low phosphorus-affinity metal concentration, and a low holding capacity of phosphorus in sediments. Possible restoration measures are outlined below.

- Chemical and clay dosing

Jessie Lake sediments contain low metal concentrations with a low phosphorus-fixing capacity. We suggest a chemical and clay-dosing measure as a restoration method. Further studies are recommended to understand the efficiency of the chemical dosing in Jessie Lake.

- Aeration

Aeration by diffused air is recommended in Jessie Lake in order to prevent anaerobic conditions at the sediment-water interface. 


\section{REFERENCES}

Blais J. M. and Kalff J. (1995) "The influence of lake morphometry on sediment focusing." Limnology and Oceanography, 40 (3): 582-588.

Boers P.C.M. (1990) "The influence of $\mathrm{pH}$ on phosphate release from lake sediments." Water Research, 25: 309-311.

Boers P. C. M. and Hese O. V. (1988) "Phosphorus release from the peaty sediments of the Loosdrecht Lake (Netherlands)." Water Research, 22: 355-363.

Bostrom B. (1984) "Potential mobility of phosphorus in different types of lakes sediments." Int. Revue. Ges. Hydrobiol., 69:457-474

Bostrom B., Ahlgren I. and Bell R. (1985) "Internal nutrient loading in a eutrophic lake, reflected in seasonal variations of some sediments parameters." Verh. Int. Ver. Limnol., 22:3335-3339.

Bostrom B. and Pettersson K. (1982) Different patterns of phosphorus release from lake sediments in laboratory experiments. Hydrobiologia, 92: 415-429.

Carlson R. E. (1977) "A trophic state index for lakes." Limnology and Oceanography, 22:361-369

Dancer W.S., Eliason R. and Lekhakul S. (1998) "Microwave assisted soil and waste dissolution for estimation of total phosphorus." Commun. Soil Sci. Plant Anal., 29, 1997-2006.

Di Toro D. M. and Fitzpatrick J. J. (1993) "Chesapeake Bay sediment flux model." Technical report, Environmental Laboratory, U.S. Army Engineer Waterways Experiment Station.

Eaton A.D., Clesceri L. S. and Greenberg A. E. (1995) "Standard method for the examination of water and wastewater." $19^{\text {th }}$ Ed. APHA, AWWA and WPCF, Washington D.C.

Edmondson W. T. and Lehman J. T. (1981) "The effect of changes in the nutrient income on the condition of Lake Washington." Limnology and Oceanography, 26; 1-29

Fillios J, and Swanson W.R. (1975) "The release rate of nutrients from river and lake sediments." J. Water Pollution Control Federal, 47: 1032-1042.

Fox I. (1989) "The adsorption and release of phosphate from sediments of a river receiving sewage effluent." Water Research, 23: 725-732. 
Furumai H. and Ohgaki S. (1989) "Adsorption-desorption of phosphorus by lake sediments under anaerobic conditions." Water Research, 23: 677-683.

Goetzman J. S. (1987) "Phosphorus and the trophic status of Jessie Lake- Development of a model for future management." Grand Rapids High School science paper.

Golterman H.L., (1995) "Theorotical aspects of the adsorption of ortho-phosphate onto iron-hydroxide." Hydrobiologia, 315; 59-68.

Hakanson J. and Jansson M. (1983) Principle of lake sedimentology. Springer-Verlag, Berlin.

Heiskanen A-S and Keek A. (1996) "Distribution and sinking rates of phytonplankton, detritus, and particulate biogenic silica in the Laptev Sea and Lena River (Arctic Siberia)." Marine Chemistry, 53:229-245.

Heiskary S. A. and Wilson C.B. (1989) "The regional nature of lake water quality across Minnesota: An analysis for improving resource management." Journal of the Minnesota Academy of Science, 55 (1): 71-77.

Hieltjes A. H. and Lijklema L. (1980) "Fractionation of inorganic phosphates in calcareous sediments." Journal of Environmental Quality, 9 (3): 405-407.

Holdren G. C. and Armstrong D. E. (1980) "Factors affecting phosphorus release from intact lake sediment cores." Environ. Sci. Techn., 14: 79-87.

Hosimi M., Okada M. and Sudo R. (1981) "Release of phosphorus from sediments." Verh. Int. Verein. Lomnl., 21: 628-633.

Hu W.F., W. Lo, H. Chua, S.N. Sin and P.H.F. Yu. (2001) "Nutrient release and sediment oxygen demand in a eutrophic land-locked embayment in Hong Kong." Environment International, 26: 369-375

Ishikawa, M., and Nishimura, H., (1989) "Mathematical method of phosphate release rate from sediments considering the effect of dissolved oxygen in overlying water." Water Research, 23: 351-35.

Istavanovics V. and Somlyody L. (2001) "Factors influencing lake recovery from eutrophication--The case of Basin 1 of Lake Balton." Water Research, 35 (3): 729 735 .

Itasca Soil and Water Conservation District (ISWCD). (2000) "Information obtained from a field survey." ISWCD gathered for Jessie Lake Clean Water Partnership (copyright). 
Jorgensen S. E. (1983) Application of ecological modelling in Environmental Management. Elsevier Scientific Publishing Company, Amsterdam, Oxford, New York.

Kelderman P, and Van de Repe A. M. (1982) "Temperature dependence of sedimentwater exchange in Lake Grevlingen, S.W. Netherlands." Hydrobiologia, 92: 489490 .

Kohler C. C. and Hubert W. A. (1999) "Inland fisheries management in North America." American Fisheries Society. Bethesda, Maryland

Lampert W, and Sommer U. (1997) Limnoecology: The ecology of lakes and streams. Oxford University Press, New York, NY.

Lemmin, U. and Imboden D.M. (1987) "Dynamics of bottom currents in a small lake." Limnology and Oceanography, 32 (1): 62-75

Lijlkema L. (1977) "The role of iron in the exchange of phosphate between water and sediment", In: Goltman H. L. (ED.). Interactions between sediment and Freshwater. Junk, The Hague, 1977, pp.313-317.

Lijklema L. (1980) "Eutrophication: the role of sediments." Hydrobiol, Bull., 14:98-105.

Lijklema L. (1993) "considerations in modelling the sediment-water exchange of phosphorus." Hydrobiologia, 253:219-230.

Lijklema L., Koelmans A. A. and Portielje R. (1993) "Water quality impacts of sediment pollution and the role of early diagenesis." Wat. Sci. Tech., 28(8-9): 1-13.

Mardsen, M.W. (1989) "Lake restoration by reducing external phosphorus loading: the influence of sediment phosphorus release." Freshwater Biology, 21: 139-162.

Minnesota Department of Natural Resources (MNDNR) (1999) "Jessie Lake Fisheries." Report 1999. Grand Rapids Area Fisheries Office.

Minnesota Pollution Control Agency (MPCA) (1995) "Preparation of a diagnostic study and implementation plan for clean water partnership projects: A guidance document."

Minnesota Pollution Control Agency (MPCA). (2000) "Minnesota lake water quality assessment data: 2000."

Mortimer C. H. (1941) "The exchange of dissolved substances between mud and water in lakes." J. Ecology, 29: 280-329.

Mortimer C. H. (1942) "The exchange of dissolved substances between mud and water in lakes." J. Ecology, 30: 147-201. 
Nakajima M. (1983) "Nutrient cycle in eutrophic water-processes on sediments and gas exchange." Ph.D. Thesis, University of Tokyo, Japan.

Nurnberg G, K. (1984) "The prediction of internal phosphorus load in lakes with anoxic hypolimnia," Limnology and Oceanography, 29 (1): 111-124

Olila O, G, (1992) "Reactivity of inorganic phosphorus in sediments of shallow eutrophic lakes." PhD dissertation, The University of Florida, USA.

Perkins R. G. and Underwood G. J. C. (2000) "The potential for phosphorus release across the sediment-waterinterface in an eutrophic reservoir dosed with ferric sulphate." Water Research, 6:1399-1406.

Psenner R. (1984) "Phosphorus release pattern from sediments of a meromictic mesotrophic lake." Verh. Int. Verein. Limnol., 22: 219-228.

Petr T. (1977) "Bioturbation and exchange of chemicals in the mud-water interface", In Goltman H. L. (ed.) Interactions between sediment and Freshwater. Junk, The Hague, 1977, pp.216-226.

Petticrew, E.L, and Arocena J.M. (2001) "Evaluation of iron-phosphate as a source of internal lake phosphorus loadings." The Science of the Total Environment, 266:87-93.

Reddy K. R. Diaz O, A. Scinto L. J. and Agami M. (1995) "Phosphorus dynamics in selected weltlands and streams of the Lake Okeechobee Basin." Ecological Engineering, 5:183-207.

Reed R. and Watkins J. (1999) "Jessie Lake (31-786) Assessment Report." Itasca Soil and water Conservation District.

Ryding S-O and Forsberg C. (1977) "Sediments as a nutrient source in shallow polluted lakes." In: Goltman H. L. (ED.), Interactions between sediment and Freshwater. Junk, The Hague, 1977, pp.2274-234.

Schindler D.W. (1974) "Eutrophication and recovery in experimental lakes: Implications for lake management." Science 184: 897-899.

Sondergaard M., Kristensen P. and Jeppesen E. (1993) "Eight years of internal phosphorus loading and changes in the sediment phosphorus profile of Lake Sobygaard, Denmark." Hydrobiologia, 253:345-358.

Sondergaard M., Windofl J. and Jeppesen E. (1996) "Phosphorus fractions and profiles in the sediment of shallow Danish lakes as related to phosphorus load, sediment composition and lake chemistry." Water Research, 30(2):992-1002. 
Stumm, W. and Morgan J.J. 1996. Aquatic Chemistry; Chemical equilibria and rates in natural waters. 3rd edition. John Wiley \& Sons, Inc., New York, NY

Smits J.G.C and van der Molen D.T. (1993) "Application of SWITCH, a model for sediment-water exchange of nutrients, to Lake Veluwe in The Netherlands." Hydrobiologia, 253(2):281-300.

Sweerts, J-P, R, A, St, Louis V, and Cappenberg T. E. (1989) "Oxygen concentration profiles and exchange in sediment cores with circulated overlying waters." Freshwater. Biology, 21:401-409.

Ting D. S. and Appan, A, (1996) "General Characteristics and Fractions of phosphorus in aquatic sediments of two tropical reservoirs." Water Sci. and Tech., 34(7-8): 53-59.

Wang H. (1999) "Modeling of phosphorus dynamics in aquatic sediments with special application to a tropical reservoir." Ph.D. Thesis, Nanyang Technological University.

Wetzel, R.G. (2001) Limnology: Lake and river ecosystems. Academic Publisher, San Diego.

Williams D. J. H., Jaquet J-M. and Thomas R. L. (1976) "Forms of phosphorus in the surfacial sediments of Lake Erie.” J. Fish. Res, Board Can., 33:413-429.

Williams D. J. H., Syers J. K. Shukla S. S. and Harris R. F. (1971) "Levels of inorganic and total phosphorus in lake sediments as related to other sediment parameters." Environ. Sci. \& Tech. 5:113-1120. 